\title{
Entry of Dutch graduates to the European Community labour market
}

Citation for published version (APA):

Ramaekers, G. W. M. (1990). Entry of Dutch graduates to the European Community labour market. Researchcentrum voor Onderwijs en Arbeidsmarkt, Faculteit der Economische Wetenschappen. ROA Reports No. 7E https://doi.org/10.26481/umarep.199007E

Document status and date:

Published: 01/01/1990

DOI:

10.26481/umarep.199007E

Document Version:

Publisher's PDF, also known as Version of record

\section{Please check the document version of this publication:}

- A submitted manuscript is the version of the article upon submission and before peer-review. There can be important differences between the submitted version and the official published version of record.

People interested in the research are advised to contact the author for the final version of the publication, or visit the DOI to the publisher's website.

- The final author version and the galley proof are versions of the publication after peer review.

- The final published version features the final layout of the paper including the volume, issue and page numbers.

Link to publication

\footnotetext{
General rights rights.

- You may freely distribute the URL identifying the publication in the public portal. please follow below link for the End User Agreement:

www.umlib.nl/taverne-license

Take down policy

If you believe that this document breaches copyright please contact us at:

repository@maastrichtuniversity.nl

providing details and we will investigate your claim.
}

Copyright and moral rights for the publications made accessible in the public portal are retained by the authors and/or other copyright owners and it is a condition of accessing publications that users recognise and abide by the legal requirements associated with these

- Users may download and print one copy of any publication from the public portal for the purpose of private study or research.

- You may not further distribute the material or use it for any profit-making activity or commercial gain

If the publication is distributed under the terms of Article $25 \mathrm{fa}$ of the Dutch Copyright Act, indicated by the "Taverne" license above, 
ENTRY OF DUTCH GRADUATES TO THE

EUROPEAN COMMUNITY LABOUR MARKET

ROA-R-1990/7E

G.W.M. Ramaekers

RESEARCH CENTRE FOR EDUCATION AND THE LABOUR MARKET

Faculty of Economics and Business Administration

University of Limburg

Maastricht, December 1990 
ENTRY OF DUTCH GRADUATES TO THE EUROPEAN COMMUNITY LABOUR MARKET

National report from the Netherlands on a research project carried out for the European Commission under the aegis of the Central Services Unit for Graduate Career Services in the United Kingdom in collaboration with the Liaison Committee of Rectors' Conferences of the European Community

ROA-R-1990/7E

G.W.M. Ramaekers

RESEARCH CENTRE FOR EDUCATION AND LABOUR MARKET

Faculty of Economic Sciences

Rijksuniversiteit Limburg

Maastricht, December 1990 
This report does not represent the official policy of either the European Commission, the Liaison Committee or the Dutch Rectors' Conference on any matter treated in this ROA publication.

Ramaekers, G.W.M.

Entry of Dutch graduates to the European Community labour market / G.W.M. Ramaekers. - Maastricht: Research Centre for Education and Labour Market. Faculty of Economic Sciences, Rijksuniversiteit Limburg, - I11. - (Report / Research Centre for Education and Labour Market, ISSN 0922-8098: 1990/7E) National report from the Netherlands on a research project carried out for the European Commission under the aegis of the Central Services Unit for Graduate Career Services in the United Kingdom in collaboration with the Liaison Committee of Rectors' Conferences of the European Community. - Met 1it. opg.

ISBN 90-5321-047-4 geb.

Trefw.: arbeidsmarkt; Nederlandse studenten; Europese Gemeenschappen. 
1. INTRODUCTION 1

1.1. Objectives of the project 1

1.2. Methodology 2

1.3. Structure of the report 3

2. BACKGROUND INFORMATION 5

3. DATA COLLECTION 6

3.1. Methodology 6

3.2. Sample 6

4. FINDINGS 8

4.1. Information from employers 8

4.1.1. Receiving information 8

4.1.2. Processing information 8

4.1.3. Disseminating information 9

4.2. Visits from employers 10

4.3. Circulating names or lists of students 11

4.4. Finding employment 12

4.4.1. Mechanisms used to find employment 12

4.4.2. Mechanisms relevant to find jobs in other EC countries 12

4.5. Towards the EC labour market 13

4.6. Institutions' future plans 14

5. RECOMMENDATIONS 16

APPENDIX I : PROJECT PARTICIPANTS

APPENDIX II : INTRODUCTORY LETTER IN DUTCH AND QUESTIONNAIRE

APPENDIX III: THE TABLES

APPENDIX IV : LOCAL PUBLICATIONS 
ACKNOWLEDGEMENT

On the initiative of the Commission of the European Communities a research project on graduate entry to the European Community labour market was carried out in the context of the Commission's work on a European Community system involving the public placement services of the community for the exchange of information about vacancies and job-seekers.

The proposal for this research project arose from the Liaison Committee of Rectors' Conferences of the EC member states who were concerned to meet the needs of young graduates within the EC for information on job opportunities which the Single Market would offer them. The Liaison Committee set up a Project Steering Group consisting of:

- Sofia Corradi of the Italian Rectors' Conference;

- Harry Luttikholt, secretary-general of the Liaison Committee of Rectors' Conferences;

- Rudy de Potter of the Advisory Centre for Students of the State University of Ghent;

- Tony Raban of Cambridge University Careers Service;

- Barrie Wilson of the Employment Directorate of the European Commission.

In the course of $1988 / 1989$ the Steering Group drew up a proposal for a research project on graduate entry to the European Community labour market, designed to identify ways in which young graduates could be helped to find jobs in other EC member states. The proposal was accepted by the European Commission at the end of 1989 and the contract was awarded to the Central Services Unit for Graduate Careers Services (CSU) in the United Kingdom, working in collaboration with the Liaison Committee of Rectors' Conferences. Tony Raban was asked to become the project director.

At a meeting of the Liaison Committee of Rectors' Conferences, the Research Centre for Education and Labour Market 1 of the Faculty of Economic Sciences of the Rijksuniversiteit Limburg in Maastricht was put forward as the national correspondent for the Netherlands, responsible for carrying out the survey in this country. Within ROA Ger Ramaekers was responsible for administering the questionnaire and for writing the Dutch national report.

1. Researchcentrum voor Onderwijs en Arbeidsmarkt (ROA). 
$-i j-$

This report would never have been written without the European Commission's initiative in organising the project, the work done by the members of the Project Steering Group and the Central Services Unit in carrying out the project and last but not least the willingness of the universities to participate in the project. 
SUMMARY

In this research project on graduate entry to the labour market, designed to identify ways in which young graduates can be helped to find jobs in other EC member states, the Research Centre for Education and Labour Market of the Rijksuniversiteit Limburg in Maastricht acted as the national correspondent for the Netherlands, responsible for carrying out the survey in this country.

Until recently employer contact or graduate placement was not seen as a responsibility of universities in the Netherlands. As a consequence contacts with employers and placement of graduates are occasional and usually take place on an unstructured and informal basis:

- Information from employers is usually processed by teaching staff, on an unstructured and informal basis, and by departmental/faculty-based organisations of current students. Information on vacancies and industrial placements/relevant vacation work is usually disseminated by departments/ faculties on an ad hoc basis, namely by word of mouth and announcements on noticeboards.

- Most institutions do not employ any staff at all whose main responsibility is employer contact or graduate placement. Institutions who do so normally employ staff in departments/faculties on a part-time basis.

- The purpose of employers' visits is seldom to interview applicants for vacation work/industrial placements or for permanent employment. Employers' visits are organised mostly by student organisations.

- The circulation to employers of names or lists of students/new graduates who are seeking employment is not common practice in the Netherlands.

The unstructured and informal nature of employer liaison also becomes manifest in the way students and new graduates find employment. The three most important methods used by them are also not formalised. These methods are: speculative applications by job-seekers, press advertisements by employers and personal contacts of teaching staff.

In most institutions in the Netherlands services to help students/new graduates to find jobs already exist or their introduction within the next two years is under consideration. In more than half of the Dutch institutions a central advisory service for students and special training courses for job applicants are at present being offered. Envisaged within 
the next two years by over one third of the institutions are programmes of employers' presentations and computerised databanks of vacancies.

Although, until now, employer liaison in general is occasional, unstructured and informal, there are mechanisms at present within Dutch institutions which might enable employers from other EC member states to make contact with their students or graduates. Student exchange arrangements within the EC and the 'Bureau Buitenland' (a central service for international affairs within Dutch universities) are most often mentioned by respondents in this respect. International associations are mostly regarded as very important external sources of help for students/new graduates who want to work in another EC country. The percentage of current students or new graduates who might be interested in working in another EC member state is, however, inversely related to the duration of the working period abroad.

The various suggestions put forward by the respondents as to how the European Commission or other organisations could help current students or new graduates who might be looking for work in other EC member states can be categorised under two headings: the creation of more international jobs (e.g. international 'stage' exchange programmes, for example by upgrading existing programmes like ERASMUS) and the stimulation of graduates to apply for jobs in other EC countries (e.g. training sessions for current students on how to apply for those jobs).

Almost all institutions would be interested in participating in any system which might be set up to circulate details of vacancies for current students or new graduates on a Community-wide basis. This interest would primarily be by the institution as a whole and by advisors or advisory services for students. Three central services within the institutions are most frequently mentioned as being particularly interested: the central service for student affairs, the central service for international affairs and the central career service.

It is recommended by the Dutch national correspondent that any system which might be set up to further the mobility of graduates within the EC labour market should focus on circulating details of relevant vacation work/industrial placements and short-term vacancies for current students or new graduates on a Community-wide basis, preferably for practical reasons in the form of a computerised EC databank which should be kept up to date and 
easily accessible to all students/new graduates. Any such system should not be based on the participation of an individual faculty but on the participation of the institution as a whole. An individual institution could as a whole participate through its central service for student affairs, its central service for international affairs or its central careers service (if present). If there are no current staff available, institutions should be willing to appoint them in order for any system to succeed. Staff already available should be given appropriate training if necessary. 
1. INTRODUCTION

\subsection{Objectives of the project $^{2}$}

This research project on graduate entry to the European Community labour market was designed to identify ways in which young graduates can be helped to find jobs in other EC member states. On the basis of current practices within university education in Europe, recommendations to the European Commission can be made on the development of a general system within the EC for bringing job seeking graduates and employers closer together. This is important both in improving the opportunities available to graduates in the EC and in the development of the Community's internal labour market.

This research project has two objectives. The first is to provide a series of country reports plus an overall general report covering all the EC member states except Luxembourg which does not award university degrees. These reports will set out:

- the mechanisms by which those entering the labour market after completing their university studies ${ }^{3}$ commonly find jobs;

- the roles played by the universities themselves in this process;

- the role of other organisations, whether public, quasi-governmental or private;

- the willingness of universities to involve themselves directly in the promotion of the mobility of their graduates to work in other EC member states and their ability to provide or develop the facilities to do this.

The second objective is to make recommendations to the European Commission about:

- how any electronic data transmission system for disseminating information about vacancies or relevant background information can be fitted to the university situation:

- more generally, what sort of information can be circulated between

2. Graduate entry to the European Community labour market. Report on a Research Project carried out for the European Commission by the Central Services Unit for Graduate Careers Services in the UK \& Ireland in collaboration with the Liaison Comittee of Rectors' Conferences of the European Community, November 1990.

3. The term 'university' has been used throughout but the project has also covered other institutions at the same level such as the Polytechnics in the UK or the Grandes Ecoles in France. 
university level institutions in the EC, in what form, to whom and by whom.

\subsection{Methodology 4}

The project director was responsible for devising, in consultation with the Steering Committee and the national correspondents, the actual questionnaire and guidelines for the format of the national reports. He was also responsible for producing the overall general report, which is based on the overall statistical analysis of the survey data and on all national reports. The overall report contains a summary of the main research findings and the recommendations for the European Commission.

The basis of the project was a postal questionnaire to be sent to universities throughout the EC. The project director, in collaboration with a freelance research consultant and the Steering Group, devised a draft questionnaire in the autumn of 1989.

The Liaison Committee, working through its member conferences, organised a network of national correspondents who would be responsible for administering the questionnaire in each member-state and for writing the country report. In January-February 1990 the draft questionnaire was pre-tested in each of the EC member states on a small number of selected institutions by means of personal interviews conducted by the national correspondents with representatives of the institutions. The pre-test in the Netherlands included three universities: one university with a small number of students, one large university and one technical university. The results of this pilot phase were discussed at a meeting of the project team, the national correspondents and members of the European Commission. Appendix I contains an overview of the participants in this project. In March 1990 the questionnaire was adjusted to its final form.

The definitive questionnaires were despatched to all institutions in the sample by a series of national correspondents who undertook to carry out the

4. Graduate entry to the European Community labour market. Report on a Research Project carried out for the European Commission by the Central Services Unit for Graduate Careers Services in the UK \& Ireland in collaboration with the Liaison Committee of Rectors' Conferences of the European Community, November 1990. 
survey in their own country and to write the national report. The data collection, which took place in April-May 1990, is described in chapter 3.

In June 1990 the computer analysis of responses and the distribution of the tables to the national correspondents by the Central Services Unit (CSU) took place. In July 1990 each national correspondent produced a draft national report for his or her country. The draft national reports formed the input for the project director's overall general draft report which was produced in September 1990.

A meeting was held in September 1990 to discuss the draft reports and to agree on the final recommendations to be made to the European Commission. In October 1990 the final overall general report was produced.

\subsection{Structure of the report}

Comments on the attitudes of Dutch universities towards becoming involved in placement activities are given as background information in chapter 2.

Chapter 3 describes how and when the questionnaires in the Netherlands were distributed and returned. It also provides details of the numbers of questionnaires distributed and the numbers returned, broken down by type of institution.

The findings are presented in chapter 4 which follows the sequence of questions 8 - 32 in the questionnaire. As a consequence attention is subsequently being paid to:

- whether the university receives or obtains information from employers;

- whether employers visit the university;

- whether lists or names of students/graduates are given to employers;

- how graduates enter the labour market;

- the EC labour market;

- the future plans of the institution.

The recommendations which result from the research findings in the Netherlands are put forward in chapter 5. 
$-4-$

The report ends with four appendices which contain:

- an overview of the participants in the project;

- a copy of the questionnaire and the introductory letter;

- the tables;

- a capita selecta of relevant local publications. 


\section{BACKGROUND-INFORMATION}

In Dutch national government policy on higher education two developments are taking place which are relevant in the context of this survey on mobility of graduates within the European community labour market: the striving towards further internationalisation of higher education and the growing importance placed on the relation between education and the labour market.

Manifestations of the first development are the growing number of international (European) oriented curricula (e.g. European studies) and the increasing participation of Dutch universities in international student exchange programmes like ERASMUS.

Emphasis on the relation between education and the labour market is a relatively recent phenomenon in the Netherlands. Until recently as a general rule Dutch universities were convinced that their only responsibility was the scientific quality of the research and of the curricula they offered and that their responsibilty towards students ended the moment they had graduated. This attitude is gradually changing. It has become a policy goal of the Dutch national government that universities 'deliver' the graduates society (the labour market) needs and that graduates enter the labour market well equiped. Many universities are setting up (first) destination surveys as a first step towards this goa ${ }^{5}$. However, this does not necessarily mean that in the short-term all universities are going to play an active role as intermediaries between employers and new graduates. Some may do so. In the short-term most universities will likely confine themselves to providing some help for students/new graduates to find employment.

5. Until now there has been hardly any co-ordination between universities with regard to the way in which these surveys are carried out (e.g. the data are collected, processed and presented). 


\section{DATA-COLLECTION}

\subsection{Methodology}

After testing the draft questionnaire, described in paragraph 1.2., the national correspondent (Researchcentrum voor Onderwijs en Arbeidsmarkt) distributed the definitive questionnaires, with an introductory letter in Dutch, by post to all universities in the Netherlands (excluding the Open University) on 12th April6. The mailing was adressed to the universities' rectors. The rectors were asked to arrange for their questionnaire to be filled in by the most relevant responsible person in their institution. Four weeks later those institutions which had not yet returned the questionnaire were for the first time telephoned. In most universities it turned out to be very difficult to trace the questionnaires since they do not employ any staff whose main responsibility is employer contact or graduate placement, either centrally or in faculties. In some institutions the questionnaires could not be traced at all and at the request of the rector a new questionnaire was sent out.

After the questionnaires were returned it was necessary in some cases to conduct additional telephone interviews to clarify data.

\subsection{Sample}

The overall response was very high. Only one institution in the Netherlands, a technical university, did not return the questionnaire. The person responsible for filling in the questionnaire in this institution showed very little interest in the survey because 'graduates from technical universities have no problems whatsoever in finding employment, either in their own country or abroad'.

Among the four private institutions there are three denominational universities. The latter are financed in the same way as the state universities.

6. A copy of the definitive questionnaire and the introductory letter in Dutch is enclosed in Appendix II. 
Numbers of questionnaires sent out and returned:

Type of institution:

- state

- private

Description of institution:

- university

929

- technical university

32

- agricultural university

- business school

11

Total :

- no

$-\%$ 


\section{FINDINGS}

\subsection{Information from employers}

This paragraph deals with information received by universities from employers: what type of information is received and what mechanisms exist for dealing with it and for disseminating it to students or new graduates.

\subsubsection{Rece $\underline{\text { ving }}$ information}

One institution ( $8 \%$ ) receives absolutely no information at all of any kind from employers. Four institutions (31\%) never receive any information of any kind from employers in other EC member states (Table 5).

Institutions in the Netherlands receive information from employers in their own country more often than from employers in other EC member states. This is the case for all types of information (Table 6).

From employers in the Netherlands:

- background information and information on permanent and long term vacancies is most often regularly received;

- information on relevant vacation work/industrial placements and short term vacancies is most often occasionally received;

- information on public sector competitions is occasionally received, and, just as frequently, never received.

From employers in other EC member states:

- background information and information on public sector competitions and relevant vacation work/industrial placements is hardly ever received;

- information on permanent and long term vacancies is most often occasionally received;

- information on short term vacancies is occasionally received, and, just as frequently, never received.

\subsubsection{Processsing information}

One institution ( $8 \%$ ) in the Netherlands does not mention any pre-specified internal mechanism for handling information from employers. Three institu- 
tions (23\%) don't have any pre-specified advisory services for students in this respect (Table 7 ).

The pre-specified mechanisms in Dutch institutions for liaising with employers and/or processing information from employers - which are most frequently (by over $50 \%$ of the respondents) mentioned - are:

- teaching staff, on an unstructured and informal basis;

- department/faculty administrative staff, on an unstructured and informal basis;

- departmental/faculty-based organisations of current students;

- central organisation of current students;

- central advisor or advisory service for students (Table 8).

Among the most frequently available mechanisms only the central advisor/advisory service for students handles employer liaison on a structural and formal basis.

Both AIESEC and INTEGRAND (an employment agency) were mentioned by 5 of the 7 respondents who mentioned other (not pre-specified) mechanisms.

Teaching staff, on an unstructured and informal basis, and departmental/faculty-based organisations of current students are most frequently mentioned as the two most important methods or mechanisms in Dutch institutions for handling employer liaison (Table 9).

\subsubsection{Disseminating information}

\section{Information on vacancies}

All institutions in the Netherlands which receive information from employers on vacancies (either permanent/long-term or short-term) and public sector competitions disseminate this information to students or recent graduates (Table 10$)$. In four institutions (31\%), however, this information is only disseminated by faculties.

In Dutch universities information on vacancies and public sector competitions is usually disseminated by departments/faculties on an ad hoc basis, namely by word of mouth and announcements on noticeboards. If disseminated centrally, such information is most frequently distributed through a 
vacancy/information bulletin (Table 11).

Information on vacancies (for permanent/long-term or short-term employment) is most frequently distributed to current students nearing the end of their studies, followed by graduates seeking their first professional appointment (Table 12).

\section{Information on industrial placements/relevant vacation work}

All institutions in the Netherlands which receive information from employers on industrial placements/relevant vacation work disseminate this information to students (Table 13). In eight institutions (62\%) this information is only disseminated by faculties; in one institution only centrally.

In Dutch universities information on industrial placements/relevant vacation work is usually disseminated by departments/faculties on an ad hoc basis (by word of mouth and announcements on noticeboards). If disseminated centrally, such information is most frequently distributed through a vacancy/information bulletin. Computerised databases are not used at all for this information (Table 14).

\subsection{Visits from employers}

Question 14 was designed to identify the staff resources devoted either centrally or on a faculty/departmental basis to employer contact. Most institutions in the Netherlands do not employ any staff at all whose main responsibility is employer contact or graduate placement, either part-time or full-time. Institutions who do so normally employ staff in departments/faculties on a part-time basis (Table 15).

One important area of contact between employers and institutions of higher education is through visits made by employers to the institutions. These may be in order to give general information to students about career opportunities or to interview applicants.

The majority of the institutions are visited by employers who wish to make contact with students/new graduates (Table 16). In almost all institutions where this takes place, these visits are organised both centrally and on a departmental/faculty basis (Table 17). Centrally organised visits from 
employers occur more often regularly than occasionally (Table 18). Departmentally organised visits are reported as occurring equally frequently on a regular and on an occasional basis (Table 19). Employers' visits which are organised on a departmental/faculty basis are most often paid to most major faculties/departments, less often to some major faculties/departments and seldom to very few faculties/departments (Table 20).

The purpose of employers' visits is in most cases to give general information or presentations to students, to teach students how to apply for jobs and to conduct preliminary interviews with students. To interview applicants for vacation work/industrial placements or for permanent employment is seldom the purpose of such visits (Table 21).

Employers usually visit the institution through a fair or forum, either for the whole institution or for individual departments/faculties. Visits from individual employers or from small groups of employers are less widespread (Table 22).

Employers' visits are usually organised by student organisations and central staff members, namely:

- departmental/faculty-based organisations of current students;

- central organisation of current students;

- central advisor or advisory service for students;

- central administrative staff whose responsibility includes liaison with employers (Table 23).

\subsection{Circulating names or lists of students}

Circulating names or lists of students/new graduates who are seeking employment to employers is, usually for reasons of privacy, not common practice in the Netherlands. More than half of the Dutch institutions never circulate information about individual students to employers in any way at all (Table 24).

The institutions which circulate names or lists of students normally do so informally on request from employers (Table 25). This is usually done by teaching staff and student organisations (Table 26). 


\subsection{Finding employment}

This paragraph deals with the respondent's general views about the relative importance of various different mechanisms for entering the labour market.

\subsubsection{Mechanis sms us êd to fo find employment}

According to the respondents the four most important pre-specified mechanisms - at present used by students and new graduates in the Netherlands to find employment - are (in order of declining importance):

1. speculative applications by job-seekers;

2. press advertisements by employers;

3. personal contacts of teaching staff;

4. industrial placements/relevant vacation work.

These mechanisms were on the whole thought to be fairly important (Table 27). The two mechanisms which were considered to be the least important, namely computerised databases of vacancies and employer sponsorship while studying, are not (yet) common practice in the Netherlands.

With regard to some of the pre-specified mechanisms a substantial number of respondents were not able to assess the importance. This was the case with 'direct approaches by employers to job-seekers' and 'press advertisements by job-seekers', where over one third of the respondents could not indicate the importance.

Only two respondents mentioned other (not pre-specified) means used for helping students/new graduates to find employment (Table 28).

Three respondents answered question 25 whether there were any subjects where there was an important difference from the general picture (Table 29). According to all three $(23 \%)$, the importance of the various mechanisms used by students and new graduates to find employment, which were pre-specified in question 24 , does not vary in different disciplines.

\subsubsection{Mechanisms relevant to find jobs in other EC countries}

$62 \%$ of the respondents mentioned mechanisms or services at present in their institutions which might enable employers from other EC member states to make contact with their students or graduates (Table 30): 
- student exchange arrangements within the EC (explicitly mentioned by 7 respondents);

- graduate address book (explicitly mentioned by 2 respondents);

- vacancy information book (explicitly mentioned by 2 respondents);

- industrial placements/relevant vacation work (explicitly mentioned by 1 respondent).

\subsection{Towards the EC labour market}

This paragraph considers the respondents' views about the degree of interest of students or new graduates in EC mobility and what mechanisms exist or might be created to facilitate this mobility.

According to the Dutch respondents, the percentage of current students or new graduates who might be interested in working in another EC member state is inversely related to the duration of the working period abroad (Table 31).

Of the four pre-specified external mechanisms, international associations are mostly regarded as very important external sources of help for students/new graduates who want to work in another EC country; public employment services and professional associations are mostly regarded as fairly important and private employment agencies as not important (Table 32).

Over half of the respondents mentioned other (not pre-specified) services or information provided by their own institution as important sources of help for students/new graduates who want to work in another EC country (Table 33). The 'Bureau Buitenland' (a central service for international affairs within Dutch universities) was mentioned most often (by $38 \%$ ) in this respect.

Almost all respondents in the Netherlands put forward suggestions as to how the European Commission, or other organisations such as the National Rectors' Conferences, could help current students or new graduates who might be looking for work in other EC member states (Table 34). The various suggestions made can be categorised under two headings.

1. More international jobs:

- the organisations of the EC themselves should offer more 'stages' to current students; 
- international 'stages' exchange programmes, for example by upgrading existing programmes like ERASMUS;

- stimulate (multinational) companies to recruit to a greater extent personnel from other EC countries; to achieve this, a change in the mentality of employers is needed; the EC might think of special awards to stimulate this process.

2. More applicants from other EC countries:

- training sessions for current students on how to apply for international jobs;

- providing graduates with addresses of organisations in the country where they want to work which can give specific information about working in that particular country;

- providing information to graduates about relevant job opportunities and working conditions in other EC member states, possibly in the form of an EC (computerised) data bank of vacancies that should be kept up to date and easily accessible to current students and new graduates.

\subsection{Institutions' future plans}

This paragraph deals with future plans for university-based mechanisms for helping graduate placement and with the universities' interest in participating in any activities or systems which might result from this project.

In most institutions in the Netherlands services to help students/new graduates to find jobs already exist or their introduction within the next two years is being considered. In two Dutch institutions (15\%) such services do not exist at all and are not envisaged at all within the next two years (Table 35).

In more than half of the Dutch institutions:

- a central advisory service for students and special training courses for job applicants are at present being offered;

- faculty-based placement services, the development of an EC network of vacancies, a central placement service and vacancy bulletins for students/graduates are not envisaged within the next two years.

Envisaged within the next two years by over one third of the institutions are programmes of employers' presentations and computerised databanks of vacancies (Table 36 ). 
Almost all institutions in the Netherlands would be interested in participating in any system which might be set up to circulate details of vacancies for current students or new graduates on a Community-wide basis (Table 37). This interest would primarily be by the institution as a whole and by advisors or advisory services for students (Table 38 ).

According to the respondents the following three central services within the institution are particularly interested:

- central service for student affairs (mentioned 8 times);

- central service for international affairs (mentioned 5 times);

- central career service (mentioned 3 times).

Also the central policy bureau of the institution (mentioned 5 times) is important in this respect. 


\section{RECOMMENDATIONS}

In this chapter the recommendations which result from the research findings in the Netherlands are put forward.

\section{Finding 1:}

The percentage of current students or new graduates who might be interested in working in another EC member state is inversely related to the duration of the working period abroad.

Recommendation 1:

Any system which might be set up to further the mobility of graduates within the EC labour market should focus especially on circulating details of relevant vacation work/industrial placements and short-term vacancies for current students or new graduates on a Community-wide basis. The number of 'stages' available abroad could be augmented by setting up international 'stage' exchange programmes, for example by upgrading existing programmes like ERASMUS. The number of new graduates who might be interested in working in another EC member state can be augmented by training sessions for current students on how to apply for international jobs.

\section{Finding 2:}

In half of the institutions computerised databanks of vacancies either already exist or are envisaged within the next two years.

Recommendation 2:

For practical reasons it is recommended that any such system take the form of a computerised EC databank which should be kept up to date and easily accessible to students/new graduates. Such a databank could form the basis for the development of a network of computerised databanks of EC universities.

\section{Finding 3:}

Almost all institutions in the Netherlands would be interested in participating in any such system. This interest would primarily be by the institution as a whole and by advisors or advisory services for students. Three central services within the institutions are most frequently mentioned as being particularly interested: the central service for student affairs, the central service for international affairs and the central career service. Recommendation 3:

Any such system should not be based on the participation of an individual 
faculty but on the participation of the institution as a whole. An individual institution could participate as a whole through its central service for student affairs, its central service for international affairs or its central career service (if present). These central services can disseminate the information received about 'stages' and short-term employment directly to students/new graduates or transmit the information to the faculties which can disseminate the information themselves.

Finding 4:

Most institutions do not employ any staff at all whose main responsibility is employer contact or graduate placement. Institutions who do so normally employ staff only on a part-time basis.

Recommendation 4:

If there is no staff yet available, institutions should be willing to appoint them in order for any system to succeed. Staff already available should be given appropriate training if necessary. 
Tony Raban -

Project Director

University Careers Service

Stuart House

Mill Lane

Cambridge CB2 $1 \mathrm{XE}$

Rudy de Potter - member of Project Steering Committee Advisory Centre for Students State University Ghent Sint-Pietersplein 7

B-9000 Ghent

\section{NATIONAL CORRESPONDENTS:}

\section{Mr H B Putt}

Director
Central Services Unit
Crawford House
Precinct Centre
Manchester M13 9EP

Mr J Hoornaert

Hoofd Dienst Voor Studieadvies

KU Leuven

Naamsestraat 63

B-3000 LEUVEN

Belgium

\section{M le Prof P Vitoux}

Ancien Président

Université Paul Valéry

Route de Mende

BP 5043

F-34032 Montpellier Cedex

France

\section{Prof Dr J A M Heijke}

Research Centre for Education

and the Labour Market

State University Limburg

Dept of Economic Sciences/ROA

PO Box 616

NL-6200 MD Maastricht

The Netherlands

\section{EUROPEAN COMMISSION:}

Barrie Wilson

European Commission

Rue de la Loi 200

B-1049 Brussels

Ann Hughes-Hallett -

Freelance Research Consultant

White House Cottage

Moorbridge Lane

Harleston, Stowmarket

Suffolk IP14 $3 \mathrm{JH}$

Harry Luttikholt - Secretary General of

Liaison Committee

Liaison Committee of Rectors' Conferences

51 rue de la Concorde

B-1050 Brussels

\section{Mme Françoise Michaux \\ CID \\ Université Catholique de Louvain \\ Place de l'Université 16 \\ B-1348 Louvain-la-Neuve \\ Belgium}

Mrs Merethe Markvard

Head of Section

Erhvervsvejledning

Kobenhavns Universitet

Fiolstraede 24

DK-1171 Kobenhavn $\mathrm{K}$

Denmark

Prof S Corradi

Conferenza Permanente dei

Rettori delle Università

Italiane

Via Salaria 113

I-00198 Roma

Italy

\section{Mr E Campos Martins}

Director

I.D.E.S

Avenida EUA $127-1^{0}$ A

P-1700 LISBOA

Portugal
Prof Dr F Buttler

Institut für Arbeitsmarkt- und

Berufsforschung

Bundesanstalt für Arbeit

Regenburgerstrasse 104

D-8500 NURNBERG

West Germany

Dr Derek Scholefield Careers Advisory Office Administration Building University College Belfield IRL-Dublin 4 Ireland

Mr J Garcia Carrasco International Relations Universidad de Salamanca Patio de Escuelas 1 E-37008 SALAMANCA Spain

Mrs S Manousaka Relations Internationales University of Athens Panepistimiou 30 GR-10679 ATHENS Greece
Jean-Paul Wattieux

European Commission

Rue de la Loi 200

B-1049 Brussels 


\section{RESEARCHCENTRUM VOOR ONDERWIJS EN ARBEIDSMARKT}

Rector Magnificus

\author{
Maastricht, 17 me i 1990 \\ Onderwerp:
}

\author{
Uw referentie: \\ Onze referentie: ROA $\quad$ GR $\backslash J P \backslash 90.1245$
}

Geachte heer,

In opdracht van de Europese Commissie wordt bij alle universiteiten in de lidstaten van de Europese Gemeenschap nagegaan welke aktiviteiten momenteel door universiteiten worden verricht om afgestudeerden te helpen bij het vinden van een baan. Op basis van het inzicht dat door deze inventarisatie wordt verkregen kunnen aanbevelingen aan de Europese Commissie worden gedaan voor het opzetten van een systeem in Europees verband waarmee werkzoekende academici en werkgevers dichter bij elkaar kunnen worden gebracht en waarmee pas afgestudeerde academici kunnen worden geholpen bij het vinden van banen in andere lidstaten van de Europese Gemeenschap. Dit is niet alleen in het belang van de afgestudeerden maar ook van groot belang voor de ontwikkeling van de interne arbeidsmarkt van de Europese Gemeenschap.

Het onderzoekproject, waarbij alle lidstaten van de Europese Gemeenschap zijn betrokken, staat onder supervisie van de Central Services Unit for Graduate Careers Services (CSU) in Groot-Brittannië in samenwerking met het Liaison Committee of Rector's Conferences of Member States of the European Community. De CSU heeft ten behoeve van dit onderzoekproject een vragenlijst opgesteld waarmee alle universiteiten in Europa worden benaderd. De uitvoering van het onderzoek onder de Nederlandse universiteiten is in handen van het Researchcentrum voor Onderwijs en Arbeidsmarkt (ROA) van de Faculteit der Economische Wetenschappen van de Rijksuniversiteit Limburg.

De door uw instelling verstrekte gegevens zullen door het ROA anoniem worden verwerkt in een nationaal rapport. Op basis van de nationale rapporten van de afzonderlijke lidstaten van de Europese Gemeenschap wordt een algemeen rapport samengesteld dat betrekking heeft op de Europese Gemeenschap als geheel en waarin de aanbevelingen voor de Europese Commissie worden opgenomen.

Het ROA is ondergebracht bij de Stichting LIBER van de Faculteit der Economische Wetenschappen van de Rijksuniversiteit Limburg

Tongersestraat 53 Postbus 616 6200 MD Maastricht
Telefoon : (0)43-888120/370

Telefax : (0)43-210999 
Als bijlage treft $u$ een exemplaar van de vragenlijst aan. U wordt vriendelijk verzocht om uw medewerking aan dit Europese initiatief te verlenen door deze vragenlijst zo spoedig mogelijk door de meest aangewezen persoon of instantie binnen uw universiteit te laten invullen en aan het ROA te retourneren. Voor de goede orde is het wenselijk dat uw secretariaat zo spoedig mogelijk aan het ROA doorgeeft wie binnen uw universiteit belast zal worden met het invulien en retourneren van de vragenlijst. Eventuele nadere inlichtingen kunnen worden verkregen bij drs. G.W.M. Ramaekers, telefoonnummer 043-888852, die binnen het ROA fungeert als aanspreekpunt voor het onderzoekproject.

Bij voorbaat hartelijk dank voor uw medewerking.

Hoogachtend,

Researchcentrum voor

Onderwijs en Arbeidsmarkt

Prof. dr. J.A.M. Heijke

Directeur

Bijlage: vragenlijst 
Dear Vice-Chancellor/Director,

\section{MOBILITY OF GRADUATES WITHIN THE EUROPEAN COMMUNITY LABOUR MARKET}

We are carrying out a research project on graduate placement for the European Commission. The project is designed to identify ways in which young graduates in particular can be helped to find jobs in other member states. Further details are given on the next page.

The project is being conducted under the aegis of the Central Services Unit for Graduate Careers Services in the UK in association with the Liaison Committee of Rectors' Conferences of Member States of the European Community.

This questionnaire is being sent to all university level institutions within the Community. We should be most grateful if you can kindly arrange for your questionnaire to be completed as soon as possible by the relevant responsible person in your institution (perhaps the person responsible for student affairs or liaison with employers).

We are very keen to obtain data from all the institutions concerned so that we have a balanced and representative picture on which to base our recommendations. We are sure that you will want your institution represented in the final results.

Thank you very much in anticipation for your co-operation.

Yours sincerely

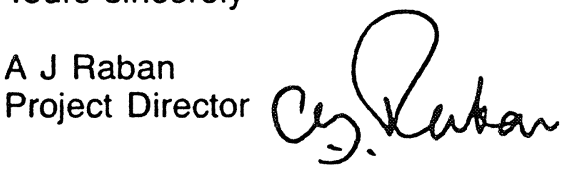

Prof $M$ Cusin

Chairman of the Liaison Committee

of EC Rectors' Conferences

Madame/Monsieur le Recteur/Président

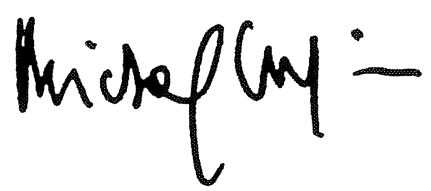

\section{MOBILITE DES DIPLOMES DANS LE MARCHE DU TRAVAIL DE LA COMMUNAUTE EUROPEENNE}

Nous effectuons un projet de recherche pour la Commission Européenne, sur le placement des diplômés. Ce projet a le but d'identifier des moyens par lesquels de jeunes diplômés en particulier peuvent être aidés à trouver du travail dans d'autres Etats membres. Vous trouverez des précisions à la page suivante.

Ce projet est mis en oeuvre sous l'égide du Bureau Central Britannique pour l'Orientation des Diplômés, en association avec le Comité de Liaison des Conférences des Recteurs des Etats Membres de la CE.

Ce questionnaire a été envoyé à tous les établissements de niveau universitaire de la Communauté. Nous vous serions très reconnaissants de vouloir bien faire remplir votre questionnaire aussitôt que possible, par la personne responsable de la question dans votre établissement (peut-être la personne responsable des liaisons avec les étudiants ou des rapports avec les employeurs).

Nous tenons beaucoup à recevoir des données de la part de tous les établissements concernés pour pouvoir obtenir une image équilibrée et représentảtive sur laquelle baser nos recommandations. Nous sommes sûrs que vous voudrez que votre établissement soit représenté dans les conclusions.

En vous remerciant par avance de votre coopération, nous vous prions d'agréer, Madame/Monsieur le Recteur/Président, l'assurance de nos sentiments distingués.

A $J$ Raban

Directeur de Projet

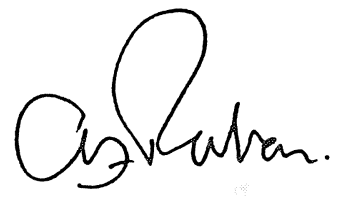

Please DO NOT FOLD this questionnaire. Veuillez NE PAS PLIER ce questionnaire.
Prof $M$ Cusin

Président du Comité de Liaison des Conférences des Recteurs des Etats Membres de la $C E$.

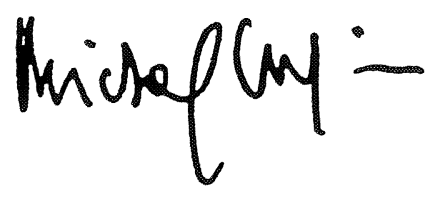




\section{GRADUATE MOBILITY IN THE EUROPEAN COMMUNITY QUESTIONNAIRE}

\section{INTRODUCTION}

In order to obtain a complete picture of the current situation, we are asking all university level institutions of higher education within the Community to help us. We should like to collect data on whether help is available to students or recent graduates in finding employment. Understanding current practices within higher education in the Community will enable us to make recommendations to the Commission on the development of a general system for bringing job-seekers and employers closer together. We see this as being very important both in improving the opportunities available to graduates in the EC and in the evolution of the Community's internal labour market.

We have aimed to keep the questions as simple as possible so that they can be answered by ticking boxes. However, in some cases a written response may be required. Please use your own language to answer these questions if this would be easier for you.

The Liaison Committee has appointed a national correspondent who is officially responsible for managing the project in your country. If you require any further advice or help in filling in the questionnaire please contact your national correspondent whose name and address appear at the bottom of page 1 .

We realise that many institutions do not provide services to job-seeking students or graduates; if this is so in your institution we should still like you to return your questionnaire. This will help us to determine whether there is a need for extra help or resources in this field.

We would like to emphasise that the information you give us will be treated as confidential and neither you nor your institution will be individually identified in our reported results.

\section{LA MOBILITE DES DIPLOMES DANS LA COMMUNAUTE EUROPEENNE}

\section{INTRODUCTION}

Afin d'obtenir une image complète de la situation actuelle, nous faisons appel à tous les établissements d'enseignement supérieur de niveau universitaire de la Communauté. Nous voudrions rassembler des données sur la question de l'assistance qui est disponible ou non aux étudiants et nouveaux diplômés pour trouver un emploi. La connaissance des pratiques actuelles de l'enseignement supérieur dans la Communauté nous permettra de formuler des recommandations à la Commission sur le développement d'un système généralisé qui mette davantage en contact les chercheurs d'emploi et les employeurs. Nous pensons que cela est très important tant pour l'élargissement des perspectives offertes aux diplômés de la CE que pour l'évolution du marché intérieur du travail dans la Communauté.

Nous avons essayé de formuler des questions aussi simples que possible, pour qu'on puisse y répondre en cochant des cases. Cependant, dans certains cas une réponse écrite peut être nécessaire. Veuillez répondre à ces questions dans votre langue si cela vous est plus facile.

Le Comité de Liaison a nommé un correspondant national qui a officiellement la responsabilité de gérer le projet dans votre pays. Pour tout renseignement ou conseil pour remplir le questionnaire, veuillez contacter votre correspondant national dont vous trouvez les co-ordonnées à la page 1 .

Nous savons que de nombreux établissements n'offrent pas de services de recherche d'emploi aux étudiants ou diplômés. Si c'est le cas pour votre établissement, nous voudrions que vous renvoyiez tout de même votre questionnaire. Cela nous aidera à déterminer s'il y a besoin d'aide ou de ressources supplémentaires dans ce domaine.

Nous voudrions insister sur le fait que les renseignements que vous nous donnerez seront considérés comme confidentiels et que ni vous même ni votre établissement ne serez identifiés individuellement dans le rapport sur nos résultats. 
This questionnaire is divided into seven sections:

1 Some details about your institution

2 Whether you receive or obtain information from employers

3 Whether employers visit your institution

4 Whether lists or names of students are given to employers

5 How graduates enter the labour market

6 The Single Market

7 Your future plans
Ce questionnaire est divisé en sept sections:

1 Quelques détails sur votre établissement

2 Information recue ou obtenue de la part d'employeurs

3 Visites d'employeurs dans votre établissement

4 Communication de listes ou noms d'étudiants aux employeurs

5 Entrée des diplômés sur le marché du travail

6 Le Marché Unique Européen

7 Vos plans pour l'avenir

IF YOUR INSTITUTION IS NOT INVOLVED WITH EMPLOYER CONTACT OR PLACEMENT, PLEASE TELL US AND RETURN YOUR QUESTIONNAIRE. ALL INFORMATION, POSITIVE OR NEGATIVE, IS USEFUL TO US.

SI VOTRE ETABLISSEMENT NE PARTICIPE A AUCUN CONTACT AVEC DES EMPLOYEURS, ET N'A PAS D'ACTIVITES D'ORIENTATION, VEUILLEZ NOUS LE DIRE ET NOUS RENVOYER VOTRE QUESTIONNAIRE. TOUTES LES INFORMATIONS, POSITIVES OU NEGATIVES, NOUS SONT UTILES.

\title{
Some Definitions
}

New graduate - a graduate who is seeking a first professional appointment

Permanent vacancies - vacancies for long term stable posts of a professional nature

Short term vacancies - vacancies for limited term posts offering useful professional experience

Relevant vacation work - work related to course of study or future career

\section{Quelques Définitions}

Nouveau diplômé - un diplômé qui cherche un premier emploi professionnel

Offres d'emploi permanent - offres d'emploi pour des postes stables de nature professionnelle

Offres d'emploi à court terme - offres d'emploi pour des postes à durée limitée offrant une expérience professionelle utile

Stage/travail de vacances approprié - stage ou travail en rapport avec les études ou la future profession

\section{SECTION I - SOME DETAILS ABOUT YOUR INSTITUTION DETAILS SUR VOTRE ETABLISSEMENT}

\author{
PLEASE ENSURE THAT YOU ANSWER QUESTIONS 1.7 \\ VEUILLEZ VERIFIER QUE VOUS REPONDEZ AUX QUESTIONS 1.7
}

\section{Q1}

Name of institution

Nom de l'établissement

Address/Adresse

Tel. No./Téléphone.

Fax/Télécopie.

In case we need to contact you again, can you please give us your name and title? Your identity and the information you give us will, of course, remain confidential to us and neither you nor your institution will be individually identified in our reported results.

Au cas où nous aurions besoin de vous re-contacter; voudriez-vous nous donner votre nom et votre titre? Votre identité et les informations que vous nous donnez resteront, évidemment, confidenticlles, et ni vous-même ni votre établissement ne serez identifiés individuellement dans notre rapport.

Name of person completing this questionnaire Nom de la personne remplissant ce questionnaire

Position/title and area of responsibility

Poste/titre et domaine de fonction

Tel. No./Téléphone 
Type of Institution/Type d'établissement

State/Public

Private/Privé

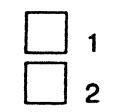

Q3

Description of Institution/Description de l'établissement University

Technical University/Université Technique

Grande Ecole

Polytechnic/Institut Universitaire de Technologie

Fachhochschule

Business School/Ecole de Commerce

Medical School/Faculté de Médecine

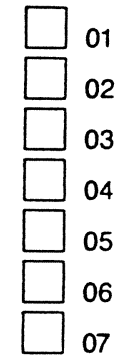

Other (please specify)

Autre (veuillez spécifier)

\section{Q4 Number of students (including}

postgraduates) in your institution at present

Nombre d'étudiants (en tous cycles)

dans votre établissement en ce moment

Approximate numbers nombre approximatif

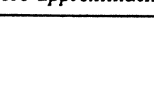

Q5 Graduate output in 1989 - number

Nombre de nouveaux diplômés en 1989

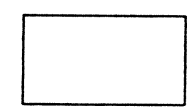

Q6

\section{Country/Pays}

Belgie/Belgique

Danmark

Deutschland

Ellada

Espana

France

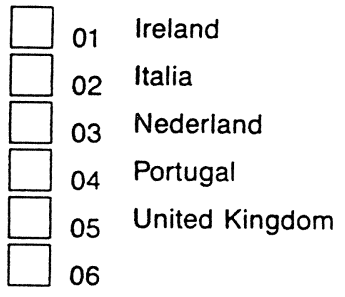

Subjects taught (ERASMUS list*)

Matières étudiées (iste ERASMUS*)

Agriculture

Architecture/Planning

Architecture/Aménagement du Territoire

Art \& Design/Art/Arts Appliqués

Business/Management Studies/

Commerce/Gestion

Education/Teacher Training

Pédagogie/Enseignement

Engineering/Technology

Ingénerie/Technologie

Geography/Geology/Géographie/Géologie

Humanities/Lettres

Languages/Philology/Langues/Philologie

Law/Droit

Mathematics/Computer Science

Mathématique/Informatique

Medical Sciences/Médecine

Natural Sciences/Sciences Naturelles

Social Sciences/Sciences Sociales

Communication/Information Sciences

Communication et sciences de l'information

Others (please specify below)

Autres domaines (veuillez spécifier ci-dessous)

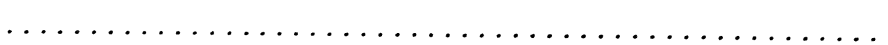

* This list is based on that used by the ERASMUS Programme. If you are not sure which subjects are included under any of these headings, the ERASMUS Directory of Programmes contains a full list.

* Cette liste est basée sur celle qui est utilisée par le programme ERASMUS. Si vous n'êtes pas súr des matières comprises dans les sections données, le Répertoire des Programmes ERASMUS en contient une liste complète.

\section{SECTION II - INFORMATION FROM EMPLOYERS INFORMATIONS VENANT D'EMPLOYEURS}

Q8 Does your institution receive or obtain information from employers on any of the following:

Est-ce que votre établissement reçoit ou obtient des informations de la part d'employeurs sur les sujets suivants:

Relevant vacation work/industrial placements Travail de vacances approprié/Stages

Short term vacancies

Emploi de courte durée à pourvoir

Public Sector Competitions

Concours du secteur public

Permanent/long term vacancies

Emplois stables/permanents

Background information from employers

(eg: publicity brochures etc)

Documentation sur les employeurs

(par ex: brochures publicitaires etc)

\begin{tabular}{|ccc|}
\hline \multicolumn{3}{|c|}{ Employers in own countrylEmployeurs de } \\
votre pays
\end{tabular}

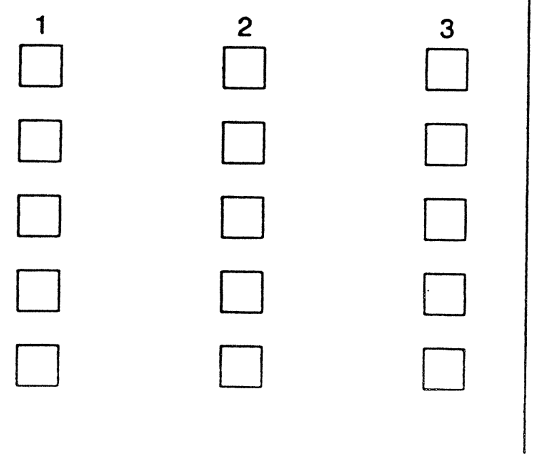

Employers in other EC countries/Employeurs d'autres pays de la $C E$

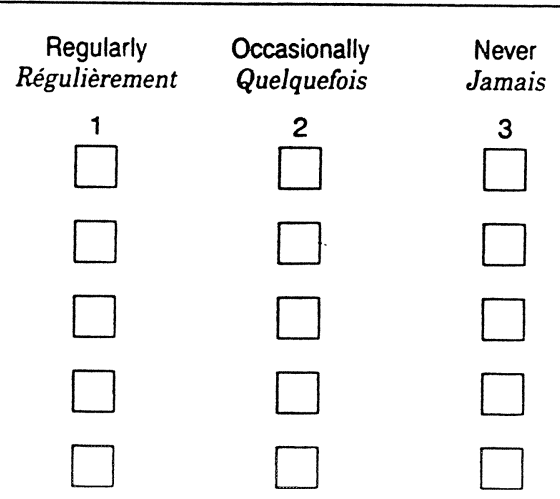


Are there any mechanisms (however informal or unstructured) in your institution for liaising with employers and/or processing information from employers?

$Y$ a-t-il des mécanismes (même non officiels ou non structurés) dans votre établissement pour effectuer la liaison avec les employeurs et/ou traiter les informations venant d'employeurs?

Please tick all those which exist in your institution Veuillez cocher tous les mécanismes qui existent dans votre établissement

\section{TEACHING STAFF/PERSONNEL ENSEIGNANT}

- on an unstructured and informal basis/sur une base non officielle et non structurée

- whose responsibility includes liaison with employers/dont les fonctions comprennent la liaison avec les employeurs

CENTRAL ADMINISTRATIVE STAFF/PERSONNEL DE L'ADMINISTRATION CENTRALE

- on an unstructured and informal basis/sur une base non officielle et non structurée

- whose responsibility includes liaison with employers/dont les fonctions comprennent la liaison avec les employeurs

\section{DEPARTMENT/FACULTY ADMINISTRATIVE STAFF/PERSONNEL ADMINISTRATIF DES}

SECTIONS/FACULTES

- on an unstructured and informal basis/sur une base non officielle at non structurée

- whose responsibility includes liaison with employers/dont les fonctions comprennent la liaison avec les employeurs

STUDENT ORGANISATIONS/ORGANISATIONS D'ETUDIANTS

- departmental/faculty-based organisations of current students/organisations d'étudiants en cours d'études basées dans les sections/facultés

- central organisation of current students/organisation centrale d'étudiants en cours d'études

- organisation of former students/organisation d'anciens étudiants

Please give name(s) of organisation(s)/Veuillez donner le nom des organisations:

\section{ADVISORY SERVICES FOR STUDENTS/SERVICES D'ORIENTATION POUR LES ETUDIANTS}

- departmental/faculty-based advisors/advisory services/services d'orientation basés dans les sections/facultés

- central advisor or advisory service (eg: Careers Service, Placement Office, Studienberatungsstelle) service central d'orientation (par ex: Service Universitaire d'Information/d'Orientation, Bolsa de Trabajol

- specialist office for industrial placements/relevant vacation work/bureau spécialisé pour les stages/e travail de vacances approprié
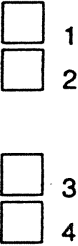

4

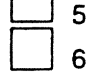

Please give name(s) of organisation(s)/Veuillez donner le nom des organisations:

\section{EXTERNAL MEANS/MOYENS EXTERNELS}

- co-operation with external services such as the public placement service/coopération avec les services de l'extérieur comme les agences publiques pour l'emploi 
Q10 Looking at this list again please tick what you think are the two most important methods or mechanisms for handling
employer liaison in your institution (ie: where most of the employer liaison is handled).

En regardant encore cette liste voulez-vous s'il vous plaît cocher les deux méthodes ou mécanismes qui, à votre avis, sont les plus importants pour assurer la liaison avec les employeurs dans votre établissement (c'est à dire où le plus grand volume de liaisons avec les employeurs est traité).

\section{TEACHING STAFF/PERSONNEL ENSEIGNANT}

- on an unstructured and informal basis/sur une base non officielle et non structurée

- whose responsibility includes liaison with employers/dont les fonctions comprennent la liaison avec les employeurs

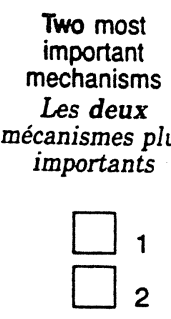

\section{CENTRAL ADMINISTRATIVE STAFF/PERSONNEL DE LADMINISTRATION CENTRALE}

- on an unstructured and informal basis/sur une base non officielle et non structurée

- whose responsibility includes liaison with employers/dont les fonctions comprennent la liaison avec les employeurs

\section{DEPARTMENT/FACULTY ADMINISTRATIVE STAFFIPERSONNEL ADMINISTRATIF DES}

\section{SECTIONS/FACULTES}

- on an unstructured and informal basis/sur une base non officielle at non structurée

- whose responsibility includes liaison with employers/dont les fonctions comprennent la liaison avec les employeurs

\section{STUDENT ORGANISATIONS/ORGANISATIONS D'ETUDIANTS}

- departmental/faculty-based organisations of current students/organisations d'étudiants en cours d'études basées dans les sections/facultés

- central organisation of current students/organisation centrale d'étudiants en cours d'études

- organisation of former students/organisation d'anciens étudiants

Please give name(s) of organisation(s)/Veuillez donner le nom des organisations:

\section{ADVISORY SERVICES FOR STUDENTS/SERVICES D'ORIENTATION POUR LES ETUDIANTS}

- departmental/faculty-based advisors/advisory services/services d'orientation basés dans les sections/facultés

- central advisor or advisory service (eg: Careers Service, Placement Office, Studienberatungsstelle) service central d'orientation (par ex: Service Universitaire d'Information/d'Orientation, Bolsa de Trabajo)

- specialist office for industrial placements/relęvant vacation work/bureau spécialisé pour les stages/ le travail de vacances approprié

Please give name(s) of organisation(s)/Veuillez donner le nom des organisations:

\section{EXTERNAL MEANS/MOYENS EXTERNELS}

- co-operation with external services such as the public placement service/coopération avec les services de l'extérieur comme les agences publiques pour l'emploi 
Is information about vacancies (either for permanent, long-term employment or for short-term professional posts) disseminated to current students/new graduates seeking their first professional employment?

Est-ce que des informations sur des postes à pourvoir (soit pour des emplois stables soit pour des emplois professionnels de courte durée) sont diffusées aux étudiants en cours d'études/aux nouveaux diplômés cherchant leur premier travail professionnel?

Please tick all those which apply Veuillez cocher toutes les réponses appropriées Centrally By department/ Not used

Centralement Par sections/ Non utilisée

By word of mouth/Oralement

By announcements on noticeboards/Par des notices sur des panneaux

Through the library/Par la bibliothèque

Through a vacancy/information bulletin/Par un bulletin sur les emplois à pourvoir/d'informations générales facultés

Through a computerised database/Par une base de données informatisée

By other means (please specify)/Par d'autres moyens (veuillez préciser lesquels)
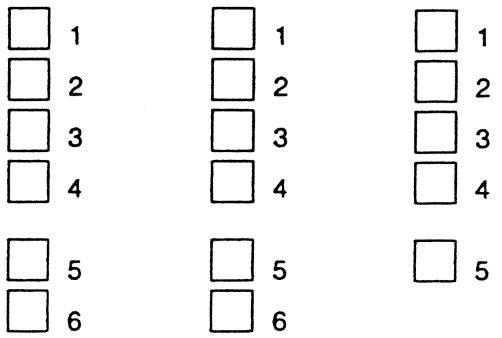

IF NO INFORMATION ON PERMANENT OR SHORT-TERM VACANCIES DISSEMINATED, GO TO QUESTION 13. SI IL N'Y A PAS DE DIFFUSION D'INFORMATIONS SUR DES POSTES A POURVOIR (SOIT POUR DES EMPLOIS STABLES SOIT POUR DES EMPLOIS PROFESSIONNELS DE COURTE DUREE) ALLEZ A LA QUESTION 13

Q12 To whom is this information about vacancies (for long-term or short-term employment) normally disseminated? A qui ces informations sur les postes à pourvoir (soit permanents, soit de courte durée) sont-elles normalement diffusées?

You may tick more than one box Vous pouvez cocher plus d'une case

Current students nearing the end of their studies/Etudiants approchant de la fin de leurs études Graduates seeking their first professional appointment/Diplômés cherchant leur premier emploi professionnel Graduates who have had some working experience/Diplômés ayant déjà eu une expérience du travail

Graduates with some working experience who attend retraining sessions/courses/Diplômés avec une certaine expérience du travail qui prennent part à des cours ou stages de formation permanente

Q13 Is information about industrial placements/relevant vacation work disseminated to students? Est-ce que des informations sur des stages ou des emplois de vacances appropriés sont communiquées aux étudiants?

Please tick all those which apply Veuillez cocher toutes les réponses appropriées

Centrally By department/ Not used

Centralement Par sections/ Non utilisée

By word of mouth/Oralement

By announcements on noticeboards/Par des notices sur des panneaux Through the library/Par la bibliothèque

Through a vacancy/information bulletin/Par un bulletin sur les emplois à pourvoir/ d'informations générales

Through a computerised database/Par une base de données informatisée

By other means (please specify)/Par d'autres moyens (veuillez préciser lesquels)

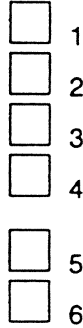
facultés
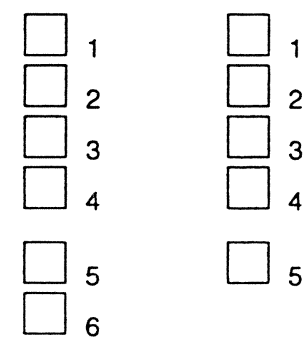


\section{SECTION III - WHETHER EMPLOYERS VISIT YOUR INSTITUTION VISITES D'EMPLOYEURS DANS VOTRE ETABLISSEMENT}

Q14 Does your institution have any part-time or full-time staff whose main responsibility is employer contact or graduate placement - either centrally or in departments/faculties?

Est-ce que votre établissement emploie du personnel à temps plein ou à temps partiel dont la fonction principale est le contact avec les employeurs ou le placement des diplômés - centralement ou dans les sections/facultés?

\begin{tabular}{|c|}
\hline CENTRALLYICENTRALEMENT \\
Please write in number/Veuillez donner le nombre
\end{tabular}

\begin{tabular}{l} 
None \\
Aucun \\
$\square$ \\
\hline
\end{tabular}

1

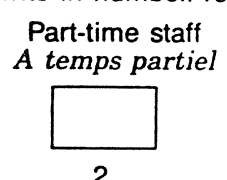

2
Full-time staff

A temps plein

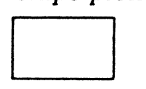

\section{IN DEPARTMENTS/FACULTIES/DANS LES SECTIONS/FACULTES}

Please write in number/Veuillez donner le nombre

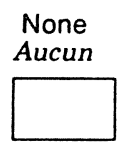

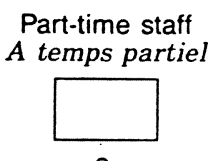

Full-time staff

A temps plein

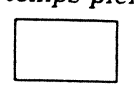

3

Q15 Do employers visit your institution to make contact with students/new graduates?

Est-ce que des employeurs viennent dans votre établissement pour prendre contact avec les étudiants/nouveaux diplômés?

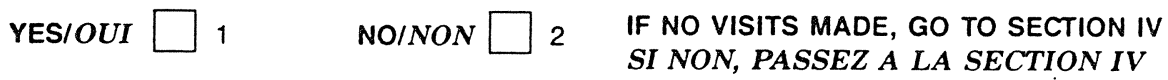

\section{IF YES/SI OUI}

Q16 Are these visits organised centrally and/or on a departmental/faculty basis? Ces visites sont-elles organisées centralement et/ou sur la base de sections/facultés?

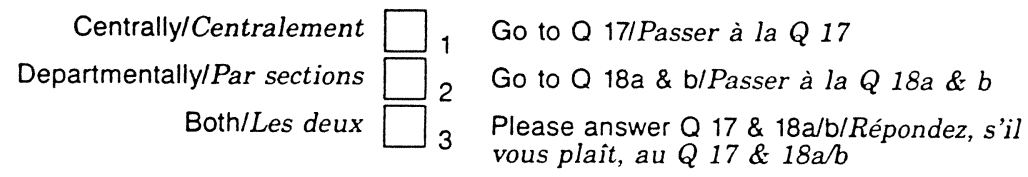

If employers' visits are organised centraliy/Si les visites d'employeurs sont organisées centralement

Q17 Are these visits regular or occasional?

Est-ce que ces visites sont régulières ou de temps en temps?

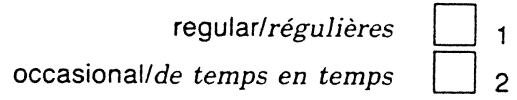

If employers' visits are organised departmentally/Si les visites d'employeurs sont organisées par sections/facultés

Q18a Are these visits regular or occasional?

Est-ce que ces visites sont régulières ou de temps en temps?

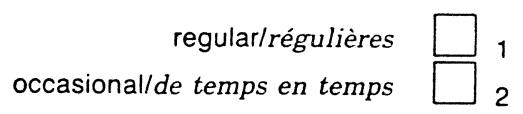

Q18b Are these visits to:

Est-ce que ces visites sont organisées dans:

most major faculties/departments/la plupart des facultés/sections importantes some major faculties/departments/quelques-unes des facultés/sections importantes very few faculties/departments/très peu de facultés/sections

If 'very few' please specify which below using the ERASMUS list on page 4

Si 'trés peu' veuillez spécifier lesquelles ci-dessous en utilisant la liste ERASMUS de la page 4 
Please answer the following questions if employers visit you regularly or occasionally

Veuillez répondre aux questions suivantes si des employeurs viennent dans votre établissement régulièrement ou de temps en temps

Q19 What is the purpose of these visits?

Quel est le but de ces visites?

You may tick more than one box

to give general information/presentations to students/donner des informations générales/faire des exposés aux étudiants

to conduct preliminary interviews with students/mener des entretiens préliminaires avec les étudiants

to interview applicants for permanent employment/mener des entretiens avec des candidats à des emplois stables

to interview applicants for vacation work/industrial placements/mener des entretiens avec des candidats à des emplois de vacances/des stages

to teach students how to apply for jobs/apprendre aux étudiants comment faire des demandes d'emploi

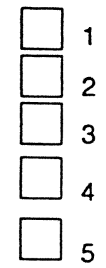

Q20 How are such visits organised?

Comment ces visites sont-elles organisées?

You may tick more than one box visits from individual employers/visites d'employeurs particuliers visits from small groups of employers/visites par de petits groupes d'employeurs

through a Fair or general forum for the whole institution/à l'occasion d'une Foire aux Emplois ou d'un forum pour tout l'établissement

through Fairs or forums for individual departments/faculties (please specify below which departments or faculties) à l'occasion de Foires ou forums pour des sections/facultés particulières (veuillez spécifier lesquelles ci-dessous) Vous pouvez cocher plus d'une case

Q21 Who organises such visits?

Qui organise de telles visites?

Please tick all those which apply Veuillez cocher toutes les réponses appropriées

\section{TEACHING STAFF/PERSONNEL ENSEIGNANT}

- on an unstructured and informal basis/sur une base non officielle et non structurée

- whose responsibility includes liaison with employers/dont les fonctions comprennent la liaison avec les employeurs

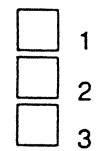

CENTRAL ADMINISTRATIVE STAFF/PERSONNEL DE LADMINISTRATION CENTRALE

- on an unstructured and informal basis/sur une base non officielle et non structurée

- whose responsibility includes liaison with employers/dont les fonctions comprennent la liaison avec les employeurs

DEPARTMENT/FACULTY ADMINISTRATIVE STAFF/PERSONNEL ADMINISTRATIF DES SECTIONS/FACULTES

- on an unstructured and informal basis/sur une base non officielle at non structurée

- whose responsibility includes liaison with employers/dont les fonctions comprennent la liaison avec les employeurs

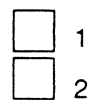

\section{STUDENT ORGANISATIONS/ORGANISATIONS D'ETUDIANTS}

- departmental/faculty-based organisations of current students/organisations d'étudiants en cours d'études basées dans les sections/facultés

- central organisation of current students/organisation centrale d'étudiants en cours d'études

- organisation of former students/organisation d'anciens étudiants

Please give name(s) of organisation(s)/Veuillez donner le nom des organisations:

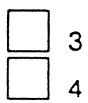

3
4

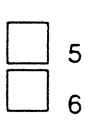

\section{ADVISORY SERVICES FOR STUDENTSISERVICES D'ORIENTATION POUR LES ETUDIANTS}

- departmental/faculty-based advisors/advisory services/services d'orientation basés dans les sections/facultés

- central advisor or advisory service (eg: Careers Service, Placement Office, Studienberatungsstelle)/ service central d'orientation (par ex: Service Universitaire d'Information/d'Orientation, Bolsa de Trabajo)

- specialist office for industrial placements/relevant vacation work/bureau spécialisé pour les stages/e travail de vacances approprié

Please give name(s) of organisation(s)/Veuillez donner le nom des organisations: 


\section{SECTION IV - CIRCULATION OF STUDENT LISTS/DIFFUSION DE LISTES D'ETUDIANTS}

Q22 Are names or lists of students/new graduates who are seeking employment circulated to employers?

Est-ce que des listes d'étudiants/de nouveaux diplômés qui cherchent un emploi sont diffusées aux employeurs?

on the institution's initiative sur l'initiative de l'établissement

on request from employers as standard practice

à la demande des employeurs, de facon régulière

informally on request from employers à la demande des employeurs, sans règle fixe

\section{Centrally \\ Centralement}

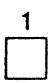

\section{By most major}

faculties/depts

Par la plupart

By some major

faculties/depts des facultés/sections des facultés/sections importantes

importantes

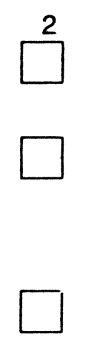

By very few

faculties/depts

Par très peu de

facultés/sections
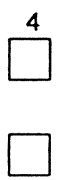

If 'very few' please specify which below using the ERASMUS list on page 4

Si 'très peu' veuillez spécifier lesquelles cidessous en utilisant la liste ERASMUS à la page 4

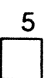

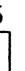

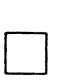

Never

Jamais

.

Q23 How is this organised?

Comment cela est-il organisé?

- by teaching staff par le personnel enseignant

- by administrative staff par le personnel administratif

- by student organisations par les organisations des étudiants

- by advisory services for students par les services d'orientation pour les étudiants

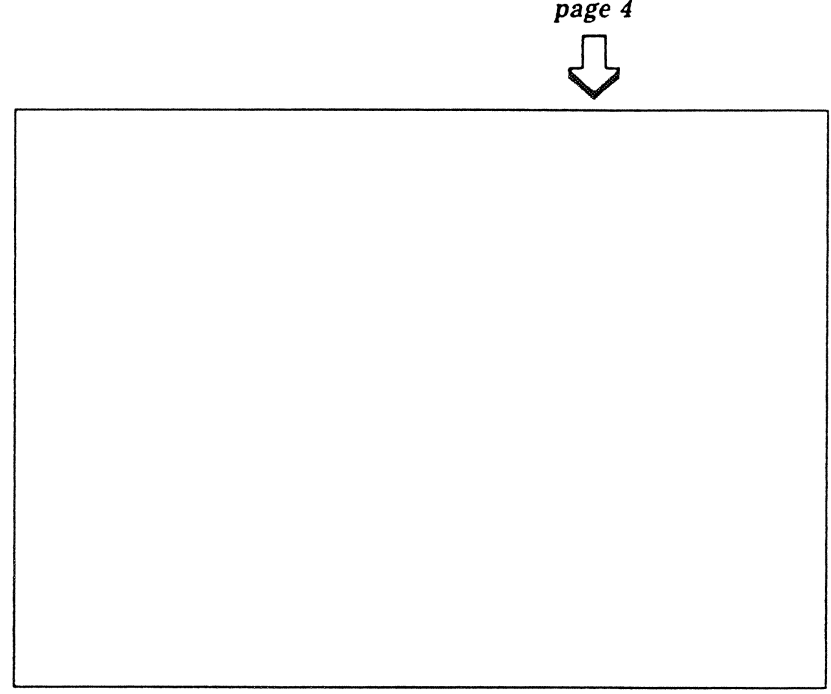




\section{SECTION V - HOW DO GRADUATES ENTER THE LABOUR MARKET? ENTREE DES DIPLOMES SUR LE MARCHE DU TRAVAIL}

Q24 Graduates find employment in a variety of ways. We have listed below a number of possible mechanisms which may be used by students and new graduates. We would like to know how important you think each of these mechanisms is in your institution at present in helping students/new graduates to find employment.

Les diplômés trouvent du travail de facons diverses. Nous avons énumeré ci-dessous un certain nombre de mécanismes possibles qui peuvent être utilisés par les étudiants et les nouveaux diplômés. Nous voudrions connaître votre avis sur l'importance relative de ces mécanismes dans votre établissement, en ce moment, pour aider les étudiants/nouveaux diplômés à trouver du travail.

please tick ONE box in each row Veuillez cocher UNE case dans chaque ligne

Personal contacts of teaching staff

Contacts personnels du personnel enseignant Not at all Not used Don't know

Speculative applications by job-seekers

Candidatures spontanées par les demandeurs d'emploi

Direct approaches by employers to job-seekers

Démarches directes des employeurs vers les demandeurs d'emploi

Employer sponsorship while studying

Parrainage d'employeurs pendant les études

Industrial placements/relevant vacation work

Stages/travail de vacances approprié

Student organisations

Organisations d'étudiants

Job Fairs

Foires aux Emplois/Forums

Vacancy information provided by your departmental/faculty advisory service(s)

Informations sur les emplois à pourvoir fournies par votre service d'orientation par faculté/section

Vacancy information provided by your central advisory service

Informations sur les emplois à pourvoir fournies par votre service central d'orientation

Training sessions to teach students how to apply for jobs

Séances de formation pour apprendre aux étudiants comment demander des emplois

Computerised database of vacancies (please specify which one, below) Base de données informatisée sur les emplois à pourvoir (veuillez préciser laquelle ci-dessous)

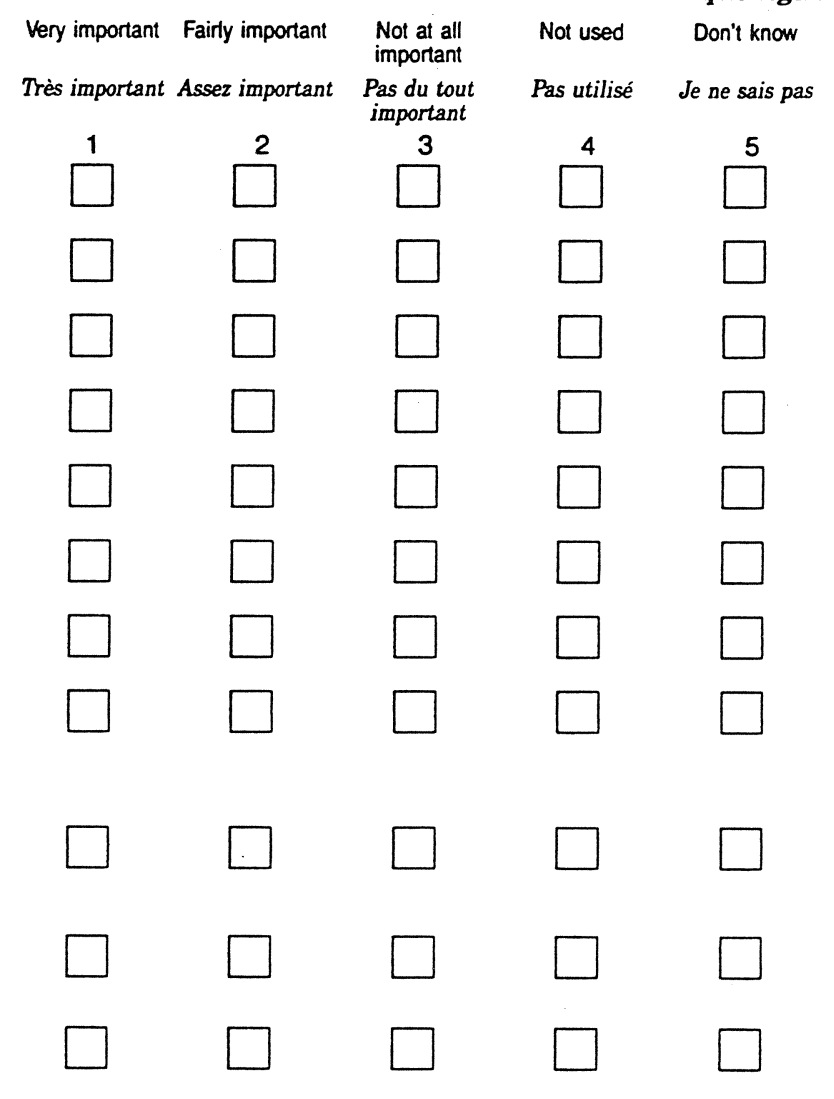

Family or friends

Famille ou amis

Press advertisements by employers

Annonces dans la presse par les employeurs

Press advertisements by job-seekers

Annonces dans la presse par les demandeurs d'emploi

Public placement services (eg: Ministry of Labour)

Services de recrutement publics (par ex: Ministère du Travail)

Private head-hunters/recruitment agencies

"Chasseurs de têtes" privés/agences de recrutement privés

Professional associations (eg: of engineers, lawyers etc)

Associations professionnelles (par ex: ingénieurs, avocats etc)

Other mechanisms (please specify below and rate for importance)

Autres mécanismes (veuillez spécifier et en évaluer

l'importance ci-dessous)

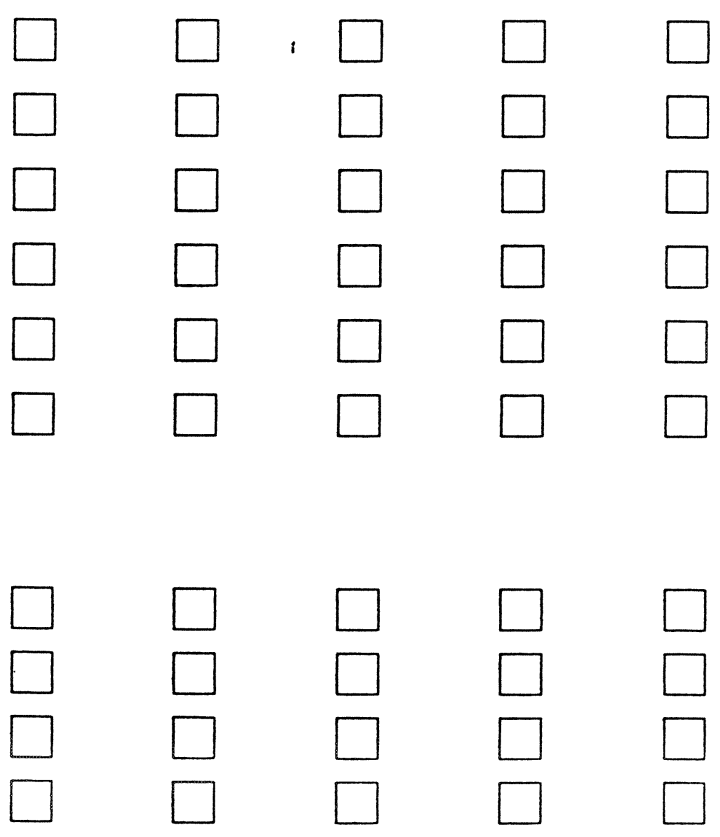


Q25 In the previous question we asked for a general assessment of the importance of various mechanisms in assisting new graduates to find employment. However, the picture may vary in different disciplines. For example, industrial placements might be the most important mechanism for engineers or professional associations for lawyers.

If there are any subjects where there is an important difference from the general picture (see Q24), please would you note them briefly below.

For example: architecture - employer sponsorship very important geography - student association very important art \& design - vacation work not at all important

Dans la question précédente nous vous avons demandé une opinion générale sur l'importance de divers mécanismes aidant les nouveaux diplômés à trouver du travail. Cependant, le tableau peut être différent suivant les matières étudiées. Par exemple, les stages peuvent être le mécanisme le plus important pour les ingénieurs ou les associations professionnelles pour les avocats.

S'il-y-a des différences importantes par rapport au tableau général (voir Q24) pour quelques-unes de ces matières, veuillez les préciser très brèvement ci-dessous.

Par exemple: architecture - parrainage d'employeurs très important

géographie - association d'étudiants très important

arts appliqués - stages pas du tout importants

Please answer in your own language if this would be easier for you

Vous pouvez répondre dans votre propre langue si cela vous est plus facile

Q26 Are there any other important mechanisms or services in your institution at present which are relevant to the recruitment of young graduates - especially those which might enable employers from other EC member states to make contact with your students or graduates? (For example: international associations, student exchange arrangements within the EC, academic networks, international vacancy bulletins etc)

Y a-t-il d'autres mécanismes ou services importants dans votre établissement en ce moment qui sont en rapport avec le recrutement de jeunes diplômés - surtout ceux qui permettraient à des employeurs d'autres pays membres de la $C E$ de prendre contact avec vos étudiants ou vos diplômés? (Par exemple: associations internationales, échanges d'étudiants dans la $C E$, réseaux universitaires, bulletins de petites annonces internationales etc)

Please answer in your own language if this would be easier for you

Vous pouvez répondre dans votre propre langue si cela vous est plus facile 


\section{SECTION VI - THE SINGLE MARKET/LE MARCHE UNIQUE EUROPEEN}

Q27 What percentage of your current students or new graduates do you think might be interested in working in another EC member state?

Quel pourcentage de vos étudiants en cours d'études ou de vos nouveaux diplômés, à votre avis, serait intéressés par un emploi dans un autre Etat membre de la CE?

Undertaking a vacation job or industrial placement in another EC member-state

Travail de vacances ou stage dans un autre Etat membre de la $C E$

Working for a short period in another EC member-state

Travail à court terme dans un autre Etat membre de la $C E$

Working long-term in another EC member-state

Travail à long terme dans un autre Etat membre de la $C E$

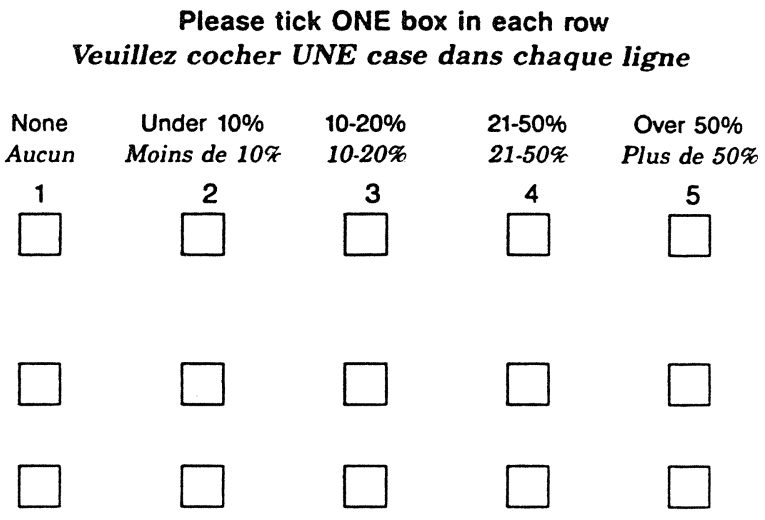

Q28 What do you regard as important sources of help for students/new graduates who want to work in another EC country? Que considérez-vous être des sources importantes d'aide pour les étudiants/nouveaux diplômés qui veulent travailler dans un autre pays de la CE?

Private employment agencies

Agences de recrutement privées

Please tick ONE box in each row Veuillez cocher UNE case dans chaque ligne

Public employment services

Services publics de recrutement

International associations

Associations internationales

Professional associations

Associations professionnelles

Very important
Très important

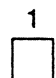

Fairly important Assez important

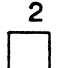

2
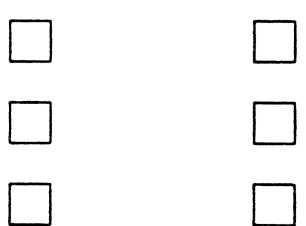

Not important Pas important<smiles>[CH]</smiles>

Services or information provided by your own institution (please specify and rate for importance) i Services ou informations fournies par votre établissement (veuillez spécifier et en évaluer l'importance)

Others (please specify and rate for importance)

Autres (veuillez spécifier et en évaluer l'importance) 
Have you any suggestions as to how the European Commission or other organisations such as the national Rectors' Conferences could help your current students or new graduates who might be looking for work in other EC member states?

Avez-vous des suggestions sur la facon dont la Commission Européenne, ou d'autres organisations comme les Conférences Nationales des Recteurs, pourraient aider vos étudiants en cours d'études ou vos nouveaux diplômés qui chercheraient un emploi dans un autre Etat membre de la CE?

PLEASE WRITE IN YOUR SUGGESTIONS USING YOUR OWN LANGUAGE IF THIS WOULD BE EASIER FOR YOU.

VEUILLEZ DONNER VOS SUGGESTIONS EN UTILISANT VOTRE PROPRE LANGUE SI CELA VOUS EST PLUS FACILE. 


\section{SECTION VII - YOUR FUTURE PLANS/VOS PLANS POUR L'AVENIR}

Q30 Some of our contacts have told us they are considering the introduction of new services to help students/new graduates to find jobs. Could you please tell us about your plans by ticking the appropriate boxes below? If you have no plans within the next 2 years, please tick the boxes on the right hand side.

Quelques-uns de nos contacts nous ont dit qu'ils avaient l'intention d'introduire de nouveaux services pour aider les étudiants/les nouveaux diplómés à trouver du travail. Pourriez-vous s'il vous plaît nous informer de vos plans en cochant les cases appropriées ci-dessous? Si vous n'avez pas de plans avant deux ans, veuillez cocher les cases de droite.

Recruitment Fairs or Forums for employers

Foires de recrutement ou forums pour employeurs

Programme of employers' presentations

Programme de présentations d'employeurs

Special training courses for job applicants

Cours spéciaux pour candidats à l'emploi

Computerised data bank of vacancies

Banque de données sur ordinateur pour les emplois à pourvoir

Vacancy bulletins for students/graduates

Bulletins de petites annonces pour étudiants/diplômés

Development of an EC network for vacancies

Développement d'un réseau de la $C E$ pour les emplois

à pourvoir

Central advisory service for students within your institution Service central d'information/d'orientation pour étudiants dans l'établissement

Faculty-based advisory services for students

Services d'information/d'orientation basés dans les facultés/sections

Central placement service

Service central de placement

Faculty-based placement services

Services de placement basés dans les facultés/sections
Please tick ONE box in each row Veuillez cocher UNE case dans chaque ligne
Already exists

Existe déjà

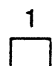

1
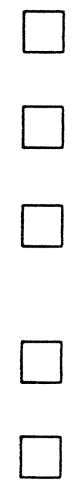

$\square$<smiles>C1CCCC1</smiles>

Within next 2 years/Avant deux ans

$\begin{array}{lcc}\begin{array}{c}\text { Definitely } \\ \text { planned }\end{array} & \begin{array}{c}\text { Under } \\ \text { consideration }\end{array} & \text { Not envisaged } \\ \text { Certain } & \text { Possible } & \text { Non projeté }\end{array}$<smiles>C1CCCC1</smiles>

3
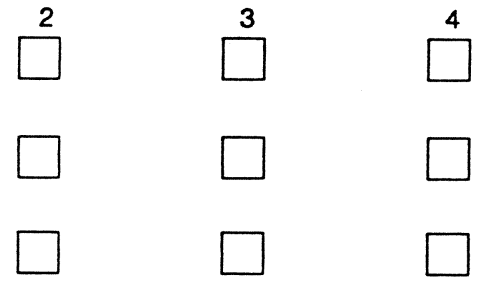

$\square$<smiles>C1CCC1</smiles><smiles>C1CCC1</smiles><smiles>C1CCCC1</smiles><smiles>C1CCC1</smiles><smiles>C1CCCC1</smiles><smiles>C1CCCC1</smiles><smiles>C1CCCC1</smiles><smiles>C1CCC1</smiles><smiles>C1CCC1</smiles><smiles>C1CCC1</smiles>

Any others (please specify and rate below)

Autres (veuillez spécifier et en évaluer l'importance cidessous) 
Q31 Would you or your institution be interested in participating in any system which might be set up to circulate details of vacancies for current students or new graduates, on a Community-wide basis?

Est-ce que vous-même ou votre établissement seriez intéressé à participer à un système qui pourrait être établi pour faire circuler les détails d'emplois à pourvoir aux étudiants en cours d'études ou aux nouveaux diplômés, pour toute la Communauté?

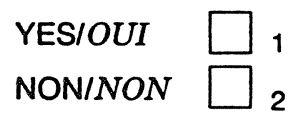

IF YOU ARE INTERESTED IN PARTICIPATING IN SUCH A SYSTEM

SI VOUS ETES INTERESSE A PARTICIPER A UN TEL SYSTEME

Q32 Would this interest be by:

Est-ce que cet intérêt viendrait:

the institution as a whole

de l'établissement entier

individual faculties

des facultés particulières

advisors or advisory services for students

des conseillers/services d'information pour étudiants

3

student organisations

des organisations d'étudiants

any others? (please specify below)

d'autres? (veuillez spécifier ci-dessous)

WE WOULD BE VERY GRATEFUL IF YOU WOULD NOTE DOWN THE NAMES AND ADDRESSES OF THE PEOPLE IN YOUR INSTITUTION WHOM WE SHOULD CONTACT OR INFORM ABOUT DEVELOPMENTS WHICH RESULT FROM THIS PROJECT. NOUS VOUS SERIONS TRES RECONNAISSANTS D'ECRIRE LE NOM ET LADRESSE DES PERSONNEL TRAVAILLANT DANS VOTRE ETABLISSEMENT A CONTACTER POUR LES TENIR AU COURANT DE DEVELOPPEMENTS QUI RESULTERONT DE CE PROJET

1 Name/Nom

Address/Adresse

2 Name/Nom

Address/Adresse

3 Name/Nom

Address/Adresse

4 Name/Nom

Address/Adresse 


\section{APPENDIX III. THE TABLES}

Unless indicated otherwise:

- the first figures in the tables are always percentages for the Dutch institutions in the survey, based on the total number of 13;

- the figures between brackets () are always percentages for all European institutions in the survey, based on the total number of 389 .

* Single response item(s)

** Multiple response item(s)

Throughout the tabulations N.A. = 'not answered'. This category can include both cases where the question was not answered when it should have been, cases where it was incorrectly answered and also cases where it was not answered because it was not applicable.

Table 1. Type of institution (Q. 2)*

$\begin{array}{lr}\text { State } & 69(85) \\ \text { Private } & 31(14) \\ \text { N.A. } & 0(1)\end{array}$

Table 2. Description of institution (Q. 3$)^{*}$

$\begin{array}{lc}\text { University } & 69(58) \\ \text { Technical university } & 15(4) \\ \text { Grande ecole } & 0(8) \\ \text { Polytechnic } & 0(12) \\ \text { Fachhochschule } & 0(11) \\ \text { Business school } & 8(2) \\ \text { Medical school } & 0(1) \\ \text { Other answer } & 8(4) \\ \text { N.A. } & 0(1)\end{array}$

Table 3. Number of students (incl. post graduates) currently (Q. 4)*

$\begin{array}{rr}<500 & 0(9) \\ 500-999 & 8(9) \\ 1000-2999 & 0(11) \\ 3000-4999 & 0(12) \\ 5000-7499 & 23(14) \\ 7500-9999 & 8(10) \\ 10000-14999 & 23(12) \\ 15000-19999 & 23(7) \\ 20000-29999 & 15(7) \\ 30000 \& \text { over } & 0(7) \\ \text { N.A. } & 0(1)\end{array}$


Table 4. Graduate output in 1989 (Q. 5)*

$\begin{array}{rr}<300 & 0(24) \\ 300-499 & 8(8) \\ 500-699 & 0(8) \\ 700-999 & 15(3) \\ 1000-1499 & 15(8) \\ 1500-1999 & 8(12) \\ 2000-2999 & 31(7) \\ 3000-4999 & 23(11) \\ 5000 \text { \& over } & 0(7) \\ \text { N.A. } & 0(11)\end{array}$

Table 5. Information received from employers; column percentages (Q. 8)*

$\begin{array}{ll}\text { Employers in } & \text { Employers in } \\ \text { own country } & \text { other EC countries }\end{array}$

$\begin{array}{lrr}\begin{array}{l}\text { Any regularly } \\ \text { None regularly, some }\end{array} & 62(69) & 8(12) \\ \text { occasionally } & 31(26) & 46(54) \\ \text { Never receive any } & 8(5) & 38(33) \\ \text { N.A. } & 0(1) & 8(1)\end{array}$

Table 6. Kind of information received from employers; row percentages (Q. 8)*

In own country, on:

Regularly Occasionally Never N.A.

Relevant vacation work/

industrial placements

Short term vacancies

$31(30) \quad 38(51)$

$15(48) \quad 38(33)$

$38(49) \quad 31(34)$

(12)

$23(18)$

38 (17)

$23(16)$

Public sector competitions

Permanent/long term vacancies

$54(42)$

$38(42)$

$8(14)$

$0(2)$

In other EC countries, on:

Relevant vacation work/

industrial placements

0 ( 5) $38(44)$

$0(2) \quad 46(33)$

$54(50)$

$8(1)$

Short term vacancies

0 (6) 31 (24)

$46(64)$

$8(1)$

Public sector competitions

$8(3) \quad 46(38)$

$62(69)$

$8(1)$

Permanent/long term vacancies

$38(58)$

$8(1)$

Background information

from employers

0 ( 3$) \quad 23(35)$

$69(61)$

$8(1)$

Table 7. Mechanisms for liaising with or processing information from employers (Q. 9)*

Internal means:

- any pre-specified internal means 92 (97)

- no pre-specified internal means 8 ( 3 )

Advisory services for students:

- any pre-specified services 77 (78)

- no pre-specified services 23 (22) 
Table 8. Kind of mechanisms for liaising with or processing information from employers (Q. 9$)^{\star *}$

Teaching staff:

- on an unstructured/informal basis

- whose responsibility includes liaison with employers

Central administrative staff:

- on an unstructured/informal basis

- whose responsibility includes liaison with employers

Department/faculty administrative staff:

- on an unstructured/informal basis

- whose responsibility includes liaison with employers

Student organisations:

- departmental/faculty-based organisations of current students

- central organisation of current students

- organisation of former students

Advisory services for students:

- departmental/facul ty-based advisors/advisory services 38 (28)

- central advisor or advisory service

- specialist office for industrial placements/relevant vacation work

Co-operation with external services

N.A.

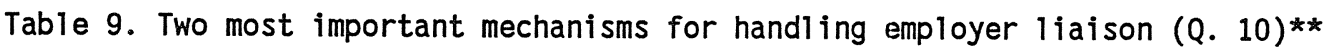

Teaching staff:

- on an unstructured/informal basis

- whose responsibility includes liaison with employers

Central administrative staff

- on an unstructured/informal basis

- whose responsibility includes liaison with employers

Department/faculty administrative staff:

- on an unstructured/informal basis

- whose responsibility includes liaison with employers

Student organisations:

- departmental/faculty-based organisations of current students

- central organisation of current students

- organisation of former students

Advisory services for students:

- departmental/faculty-based advisors/advisory services

- central advisor or advisory service

- specialist office for industrial placements/relevant vacation work

Table 10. Disseminating information about vacancies (either for permanent, long-term employment or for short-term professional posts) to current students/new graduates (Q. 11)* 
Table 11. Ways of disseminating information about vacancies (either for permanent, long-term employment or for short-term professional posts) to current students/new graduates (Q. 11$)^{\star *}$

$\begin{array}{lccc} & \text { Centra11y } & \begin{array}{c}\text { By department/ } \\ \text { faculty }\end{array} & \text { Not used } \\ \text { By word of mouth } & 15(24) & 92(50) & 8(34) \\ \text { By announcements on noticeboards } & 23(57) & 77(61) & 8(9) \\ \text { Through the library } & 15(14) & 0(6) & 69(73) \\ \text { Through a vacancy/information bulletin } & 31(39) & 8(11) & 54(48) \\ \text { Through a computerised database } & 15(12) & 0(3) & 62(75) \\ \text { By other means } & 15(16) & 8(4) & --(--) \\ \text { N.A. } & 38(29) & 8(29) & 8(11)\end{array}$

Table 12. To whom information about vacancies (either for permanent, long-term employment or for short-term professional posts) is disseminated (Q. 12)**

Current students nearing end of studies

Graduates seeking first professional appointment

Graduates who have had some working experience

Graduates with some working experience who attend retraining

N.A.

Table 13. Disseminating information about industrial placements/relevant vacation work to students (Q. 13)*

Disseminated any means mentioned

No mention of dissemination

Number of institutions where

this information is received $(=100 \%)$

Table 14. Ways of disseminating information about industrial placements/relevant vacation work to students (Q. 13)**

By word of mouth

By announcements on noticeboards

Through the library

Through a vacancy/information bulletin

Through a computerised database

By other means

N.A.

Centrally By department/
faculty

$\begin{array}{rr}15(25) & 85(51) \\ 15(53) & 69(60) \\ 8(10) & 0(6) \\ 23(27) & 0(8) \\ 0(6) & 0(2) \\ 8(10) & 8(4) \\ 69(36) & 15(30)\end{array}$

Not used

$0(30)$

$8(10)$

$85(77)$

$62(59)$

85 (83)

-- (--)

$8(10)$ 
Table 15. Staff whose main responsibility is employer contact/graduate placement; column percentages (Q. 14)*

$\begin{array}{lrc} & \text { Centrally } & \begin{array}{c}\text { In departments/ } \\ \text { faculties }\end{array} \\ \text { None } & 69(52) & 54(78) \\ \text { Part-time only } & 15(12) & 31(11) \\ \text { Full-time only } & 8(25) & 0(6) \\ \text { Part-time \& full-time } & 8(11) & 8(3) \\ \text { N.A. } & 0(1) & 8(3)\end{array}$

Table 16. Wether employers visit the institution to make contact with students/new graduates (Q. 15$)^{*}$

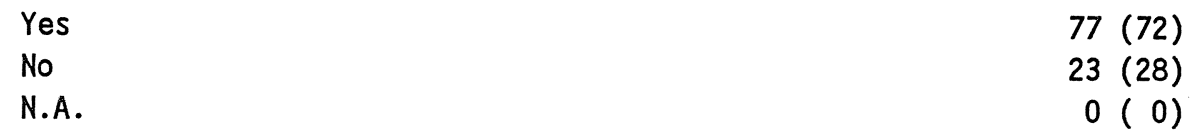

Table 17. Method of arranging visits from employers (Q. 16)*

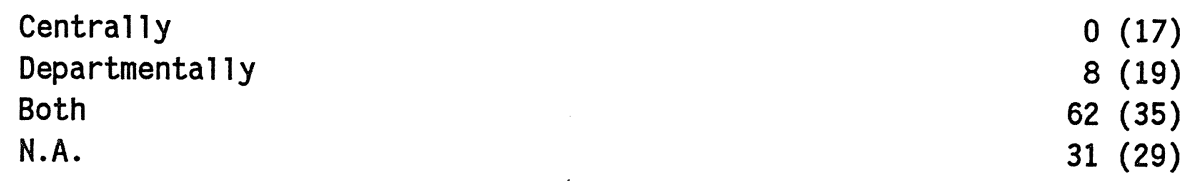

N.A.

Table 18. Frequency of visits from employers, organised centrally (Q. 17)*

$\begin{array}{ll}\text { Regular } & 38(36) \\ \text { Occasional } & 23(17) \\ \text { N.A. } & 38(48)\end{array}$

Table 19. Frequency of visits from employers, organised departmentally (Q. 18.A)*

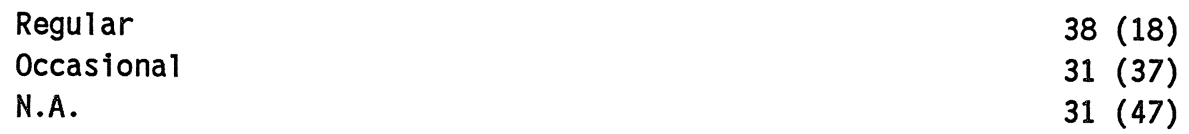

N.A.

Table 20. To whom visits from employers are made (Q. 18.B)**

Most major faculties/departments

Some major faculties/departments

Very few faculties/departments

N.A. 
Table 21. Purpose of visits by employers (Q. 19)**

To give general information/presentations to students 69 (68)

To conduct preliminary interviews with students 38 (46)

To interview applicants for permanent employment 23 (35)

To interview applicants for vacation work/industrial placements 8 (31)

To teach students how to apply for jobs 46 (25)

N.A. $\quad 31$ (29)

Table 22. Ways visits by employers are organised (Q. 20)**

Visits from individual employers $\quad 15$ (59)

Visits from small groups of employers 31 (17)

Through a fair/general forum for the whole institution 46 (33)

Through fairs/forums for individual departments/faculties 69 (22)

Other answer 23 (14)

N.A. $\quad 31$ (29)

Table 23. Who organises visits from employers (Q. 21)**

Teaching staff:

- on an unstructured/informal basis

- whose responsibility includes liaison with employers

Central administrative staff:

- on an unstructured/informal basis

- whose responsibility includes liaison with employers 31 (20)

Department/faculty administrative staff:

- on an unstructured/informal basis

- whose responsibility includes liaison with employers

- departmental/faculty-based organisations of current students 62 (20)

- central organisation of current students 38 (19)

- organisation of former students 23 (6)

Advisory services for students:

- departmental/faculty-based advisors/advisory services 15 ( 8)

- central advisor or advisory service 46 (40)

- specialist office for industrial placements/relevant vacation work 15 (10)

Any others 15 (27)

N.A. $23(29)$

Table 24. Circulation of names or lists of students/new graduates to employers (Q. 22)*

Centrally or by any department/faculty Never

$38(41)$

N.A.

$54(58)$

8 ( 1) 
Table 25. Methods of circulating names or lists of students/new graduates to employers; (Q. 22)**

$\begin{array}{cll}\begin{array}{cl}\text { On institution's } \\ \text { initiative }\end{array} & \begin{array}{l}\text { On request from } \\ \text { eployers as stan- }\end{array} & \begin{array}{l}\text { Informally on } \\ \text { request from } \\ \text { dard practice }\end{array} \\ & \text { employers }\end{array}$

$\begin{array}{lccr}\begin{array}{l}\text { Centrally } \\ \text { By most major faculties/ }\end{array} & 8(6) & 8(10) & 15(16) \\ \begin{array}{l}\text { departments } \\ \text { By some major faculties/ } \\ \text { departments }\end{array} & 0(1) & 0(2) & 0(4) \\ \begin{array}{l}\text { By very few faculties/ } \\ \text { departments }\end{array} & 0(3) & 0(1) & 15(8) \\ \begin{array}{l}\text { Never } \\ \text { N.A. }\end{array} & 77(85) & 0(2) & 0(4) \\ & 8(1) & 77(85) & 69(70) \\ 8(1)\end{array}$

Table 26. Ways circulation of names or listst of students to employers is organised (Q. 23)**

$\begin{array}{lr}\text { By teaching staff } & 15(14) \\ \text { By administrative staff } & 8(24) \\ \text { By student organisations } & 15(6) \\ \text { By advisory services for students } & 8(9) \\ \text { Other answer } & 8(5) \\ \text { N.A. } & 62(60)\end{array}$

Table 27. Importance of mechanisms for helping students/new graduates to find employment; mean figures (Q. 24)*

Mean figures based on scoring 3 for 'Very Important', 2 for 'Fairly Important' and 1 for 'Not at all Important'. 'Not used' and 'Don't Know' are both scored 0.

Personal contacts of teaching staff

Speculative applications by job-seekers

Direct approaches by employers to job-seekers

Employer sponsorship while studying

Industrial placements/relevant vacation work

Student organisations

Job fairs

Vacancy information provided by departmental/

faculty advisory service(s)

Vacancy information provided by central advisory service

Training sessions to teach students how to apply for jobs

Computerised database of vacancies

Family or friends

Press advertisements by employers

Press advertisements by job-seekers

Public placement services

Private head-hunters/recruitment agencies

Professional associations
$1.62(1.74)$

$1.92(1.93)$

0.85 (1.33)

$0.38(1.07)$

$1.54(1.78)$

$1.23(0.81)$

$1.46(1.17)$

$0.54(0.90)$

$1.08(1.51)$

$1.38(1.20)$

$0.23(0.45)$

$1.15(1.50)$

$1.85(2.20)$

$0.46(0.85)$

$0.92(1.20)$

$0.77(0.91)$

$0.92(1.02)$ 
Table 28. Any mention of not pre-specified mechanisnis used for helping students/new graduates to find employment (Q. 24)*

$\begin{array}{ll}\text { Yes } & 15(14) \\ \text { No } & 85(86)\end{array}$

Table 29. Any mention of subjects where the importance of mechanisms for helping students/new graduates to find employment differs from the general picture (Q. 25)*

$\begin{array}{ll}\text { Yes } & 23(42) \\ \text { No } & 77(58)\end{array}$

Table 30. Any mention of mechanisms/services which are relevant to the international recruitment of young graduates $(Q .26)$ *

Yes $62(40)$

No $38(60)$

Table 31. Percentage of students/new graduates who might be interested in working in another EC member state; column percentages (Q. 27)*

$\begin{array}{lll}\text { Undertaking a vacation } & \text { Working for a short } & \text { Working long- } \\ \text { job or industrial } & \text { period in another } & \text { term in another } \\ \text { placement in another } & \text { EC member state } & \text { EC member state }\end{array}$

$\begin{array}{lrrr}\text { None } & 0(1) & 0(2) & 0(2) \\ \text { Under 10\% } & 0(18) & 0(21) & 15(52) \\ 10-20 \% & 23(33) & 23(38) & 38(33) \\ 21-50 \% & 23(30) & 38(28) & 15(7) \\ \text { Over } 50 \% & 31(14) & 15(8) & 8(2) \\ \text { N.A. } & 23(3) & 23(3) & 23(4)\end{array}$

Table 32. Sources of help for working in another EC member state; column percentages (Q. 28)*

Private employment Public employment International Professional
agencies services associations associations

$\begin{array}{llrrr}\text { Very important } & 23(13) & 23(25) & 46(35) & 23(27) \\ \text { Fairly important } & 23(38) & 46(35) & 31(41) & 46(39) \\ \text { Not important } & 38(47) & 23(37) & 8(21) & 23(31) \\ \text { N.A. } & 15(2) & 8(2) & 15(3) & 8(2)\end{array}$

Table 33. Any mention of not pre-specified sources of help for working in another EC member state (Q. 28)*

Any others from own institution

Any others from outside
$62(55)$

$31(18)$ 
Table 34. Any mention of suggestions as to how the EC could help students/new graduates looking for work in other EC member states (Q. 29)*

$\begin{array}{lr}\text { Yes } & 92(61) \\ \text { No } & 8(39)\end{array}$

Table 35. Plans for the introduction within the next two years of pre-specified services to heip students/new graduates to find jobs (Q. 30)*

Any al ready exist

$77(68)$

None exist but definitely planned

$0(6)$

Under consideration only

$8(13)$

None envisaged at all

$15(13)$

N.A.

$0(1)$

Table 36. Services to help students/new graduates to find jobs, institutions have or plan to introduce within the next two years; row percentages (Q. 30)*

$\begin{array}{lll}\text { Within the next two years } & \begin{array}{l}\text { With exists } \\ \text { Definitely Under Not envisaged N.A. } \\ \text { planned consideration }\end{array}\end{array}$

Recruitment fairs or

forums for employers

Programme of employers'

$38(31)$

$0(5)$

$31(18)$

$31(46)$

$0(1)$

presentations

Special training courses

for job applicants

Computerised databank

of vacancies

Vacancy bulletins for

students/graduates

Development of an EC

network for vacancies

Central advisory service

for students within the

institution

Faculty-based advisory

services for students

Central placement service

Faculty-based placement

services

$\begin{array}{lllll}38(39) & 15(5) & 23(19) & 23(36) & 0(1) \\ 54(39) & 8(6) & 15(16) & 23(38) & 0(1) \\ 15(10) & 15(12) & 23(31) & 46(47) & 0(1) \\ 38(38) & 0(4) & 8(17) & 54(40) & 0(1) \\ 0(1) & 0(4) & 31(38) & 69(56) & 0(2) \\ 69(53) & 8(4) & 8(12) & 15(31) & 0(1) \\ 38(16) & 8(4) & 15(15) & 38(65) & 0(1) \\ 31(31) & 0(3) & 8(13) & 62(53) & 0(1) \\ 8(10) & 0(2) & 8(11) & 92(76) & 0(3)\end{array}$

Table 37. Whether the institution is interested in participating in any system to circulate details of vacancies on a community-wide basis (Q. 31)*
Yes
$92(95)$
No
$8(4)$
N.A.
$0(1)$ 
Table 38. Who is interested in participating in a system for circulating details of vacancies on a community-wide basis (Q. 32)**

The institution as a whole

Individual faculties

Advisors/advisory services for students

Student organisations

Other answer

N.A.
77 (61)

$31(23)$

$69(51)$

$31(20)$

8 ( 5)

0 ( 4$)$ 
Dam, J.W. van, A. de Grip, J.A.M. Heijke (1988), Op zoek naar informatie bronnen over de arbeidsmarktpositie van academici, ROA-W-1988/3, Maastricht.

Dam, J.W. van, J.A.M. Heijke, G.W.M. Ramaekers (1989), Ontwerp van een arbeidsmarktscanner voor academici, ROA-R-1989/3, Maastricht.

Ministerie van Onderwijs en Wetenschappen (1988), Hoger Onderwijs en Onderzoek Plan, 's-Gravenhage.

Vereniging van Samenwerkende Nederlandse Universiteiten (1988), Gids voor de externe kwaliteitszorg, Utrecht. 